\title{
Addressing Sustainability Risks of Bioenergy -Policy Strategies and Corporate Initiatives
}

\author{
Michael Krug1, Grażyna Rabczuk², Adam Cenian²,3 \\ ${ }^{1}$ Environmental Policy Research Centre, Freie Universität Berlin, Berlin, Germany \\ ${ }^{2}$ Instytut Maszyn Przepływowych PAN im. R. Szewalskiego, Gdańsk, Poland \\ ${ }^{3}$ Gdańska Szkoła Wyższa, Gdańsk, Poland \\ Email: mikru@zedat.fu-berlin.de, rabczuk@imp.gda.pl, cenian@imp.gda.pl
}

Received 27 March 2015; accepted 18 May 2015; published 20 May 2015

Copyright (C) 2015 by authors and Scientific Research Publishing Inc.

This work is licensed under the Creative Commons Attribution International License (CC BY).

http://creativecommons.org/licenses/by/4.0/

\section{(c) (i) Open Access}

\section{Abstract}

This paper focuses on the sustainable use of solid and gaseous biomass for electricity, heating and cooling. It provides updated findings of policy analyses and corporate strategy analyses performed in the frame of BIOENERGY PROMOTION, one of the flagship projects under the EU Strategy for the Baltic Sea Region. In particular, the paper highlights policies and measures which have been adopted by the EU and EU Member States to address environmental and social sustainability risks of bioenergy. Taking into account the conclusions of BIOENERGY PROMOTION, the paper identifies promising policy developments, but also shortcomings. On the Member State level, the paper refers to the examples of Germany and Poland. It illustrates how problematic policy priorities and policy malfunctioning in two sub-sectors (biogas from energy crops in Germany, biomass co-firing in Poland) led to undesirable environmental and social developments and how policies have been re-adjusted to mitigate sustainability risks. The paper also portrays a number of voluntary corporate sustainability initiatives which emerged due to the lack of a binding European sustainability framework for solid and gaseous biomass. The authors conclude that without a binding sustainability framework at EU level there is a risk of having a patchwork of potentially diverging sustainability regimes and initiatives across Europe causing market intransparency and insecurity for investors.

\section{Keywords}

Biomass, Bioenergy, Sustainability, Policy, Business Strategies

\section{Introduction}

In accordance with the Renewable Energy Directive (2009/28/EC) bioenergy is in the following defined as en-

How to cite this paper: Krug, M., Rabczuk, G. and Cenian, A. (2015) Addressing Sustainability Risks of Bioenergy-Policy Strategies and Corporate Initiatives. Energy and Power Engineering, 7, 217-241. 
ergy from biomass. Biomass means the biodegradable fraction of products, waste and residues of biological origin from agriculture (including vegetal and animal substances), forestry and related industries including fisheries and aquaculture, as well as the biodegradable fraction of industrial and municipal waste. Biofuel means liquid or gaseous fuel for transport produced from biomass. Bioliquids comprise liquid fuel for energy purposes other than for transport, including electricity and heating and cooling, produced from biomass. Biogas is a gas produced from anaerobic digestion of biomass and composed mainly of methane and carbon dioxide. Biogas can be burnt to produce heat and/or electricity or upgraded for use in vehicles that run on Compressed Natural Gas or Liquid Petroleum Gas, or upgraded and injected into local and/or national gas grids.

The focus of this paper is the use of solid and gaseous biomass for electricity, heating and cooling. Bioenergy production and use can provide multiple environmental and socio-economic opportunities and benefits. These include significant reductions of greenhouse gas (GHG) emissions compared to the use of fossil fuels, improvements in energy security and foreign trade balances, business and job opportunities along the supply chain, opportunities for economic and social development particularly in rural areas, mitigation of waste disposal problems and a better use of natural and other resources, synergies with other goals, like water protection, maintenance of biodiversity, business development, or tourism development. Furthermore, biomass is the most versatile of all renewable energy sources (RES). Biomass, unlike most other renewable energy sources, can be stored relatively easily and can provide energy to dispatch as needed [1].

On the other side, the production, extraction, processing, transport and conversion of biomass into final energy can sometimes have adverse impacts for GHG balances, biodiversity, natural habitats and ecosystem services, and soil and water quality.

In 2012 the Council of the European Union emphasized that the challenge in developing renewable energy sources not only needs to focus on making the relevant technologies more attractive and cost-efficient, but also to ensure that their entire lifecycle remains sustainable. Therefore, the Council concluded, further consideration needs to be given to the economic, environmental and social aspects of production and use of renewable energy sources. In particular the expected rise in the use of biomass in the coming years heightens the need to consider the sustainability dimensions of the use of sensitive biomass resources [2].

There are a number of environmental sustainability risks associated with increasing energy uses of biomass from forestry and agriculture. Growing demand for bioenergy has raised serious concerns about negative long term effects of removing forest residues for soil fertility, soil organic carbon, water quality and habitat. Increased harvesting and removal of forest residues and stumps for bioenergy are expected to have a greater impact on soil, water and habitat than conventional forest practices [3]. The production of dedicated energy crops can also lead to negative developments like, for instance, increased GHG emissions or biodiversity losses through fertilizer use or conversion of forest and carbon rich land into arable land.

Solid biomass imports from countries in Central Africa, South America, or Asia, but also from other non-EU countries might raise significant environmental and social sustainability concerns due to insufficient safeguards addressing deforestation and forest degradation or ensuring sustainable forest management.

The European Commission recently identified the following sustainability risks that need to be properly managed by both economic operators and Member States [4]:

- Unsustainable feedstock production;

- Emissions from land use, land use change and forestry (LULUCF);

- Lifecycle GHG emission performance;

- Indirect impacts;

- Inefficient bioenergy generation;

- Air emissions.

A recent study performed by the International Institute for Sustainability Analysis and Strategy, the European Forest Institute and Joanneum Research [5] reveals that planned demand for wood will probably outweigh the amount that can be safely and in a sustainable manner extracted from European forests. The study warns that current policies will lead to a significant increase in pressure on European and global forests, unless the potential of resources such as industrial and harvesting residues or wood from landscape management are fully mobilised-which is highly unlikely without specific incentives.

Hence, the potential of bioenergy to contribute to Sustainable Development depends very much on a case to case basis, particularly on the feedstock, land use changes, cultivation, collection and harvesting practices, transport needs, the refinement and conversion processes and conversion technologies. 
Whereas the European Union introduced a set of mandatory sustainability criteria for transport biofuels and bioliquids in the Renewable Energy Directive (RED), the introduction of sustainability criteria for solid and gaseous biomass used in electricity, heating and cooling has so far been left to the discretion of the Member States. In the absence of any binding EU wide sustainability scheme for solid and gaseous biomass energy utilities and commercial actors developed own or joined emerging voluntary sustainability schemes in the frame of their biomass procurement policies.

Sustainability challenges of bioenergy and the question how governments and enterprises respond to these challenges were a major topic of BIOENERGY PROMOTION ${ }^{1}$, a flagship project under the EU Baltic Sea Region Strategy (COM(2012) 128 final), which received funding by the European Union under the Baltic Sea Region Programme. In addition to many other project activities, the consortium commonly developed principles and criteria for sustainable bioenergy production in the Baltic Sea region, conducted policy assessments exploring European, national and regional bioenergy policies and explored voluntary corporate strategies. The purpose of this paper is to present updated findings of this research

The paper is structured as follows: firstly we will summarize key conclusions of BIOENERGY PROMOTION regarding sustainability of bioenergy. This will be followed by a summary and appraisal of recent policy developments at the European level. Furthermore, the paper analyses policies and measures adopted on the Member State level addressing the sustainability of bioenergy with a special focus on Germany and Poland. Both countries represent vivid cases illustrating the sustainability challenges and risks of two very different bioenergy pathways. They show how these risks draw public attention and debate, and how governments finally respond to it. The final chapter provides portraits of voluntary corporate sustainability initiatives in the Baltic Sea region.

\section{Sustainable Bioenergy Production and Use-Conclusions from the Project BIOENERGY PROMOTION}

Within BIOENERGY PROMOTION the project partners developed a set of principles and criteria for sustainable bioenergy production in the Baltic Sea region to provide guidance to multiple stakeholders, including policy makers, biomass producers and users, investors, non-governmental organizations (NGOs), energy companies, etc. [6]. The consortium proposed principles and criteria which apply to all types of bioenergy and cover biodiversity, resource efficiency (including land use), energy efficiency, climate change mitigation efficiency, social well-being and economic prosperity (ibid.). The principles and criteria refer to the entire supply chain including energy conversion and end use.

The consortium agreed that bioenergy systems should be developed in a way that enables substantial reductions of lifecycle GHG emissions preferably in the range of 80 per cent compared to the use of fossil fuels to achieve the EU aspiration of 80 - 95 per cent GHG emission reduction by $2050^{2}$ (see sub-chapter 3.1). The ambitious GHG performance value clearly favours the utilization of residues from European forests and agri- cultural land, of processed residues and waste. It also reflects the scepticism shared by a majority of partners concerning pathways using tropical/sub-tropical feedstock, pathways which need high fossil energy inputs, but also certain pathways utilizing annual energy crops like maize for biogas production.

Since biomass has relatively low energy densities and high land requirements, a global biomass market with large scale intercontinental trade was not regarded as a step in the right direction. Long distance transport of biomass and bioenergy carriers was also disapproved by the vast majority of project partners, particularly in com-

\footnotetext{
${ }^{1}$ BIOENERGY PROMOTION served as a major platform in the Baltic Sea region for cross-sector and transnational networking to facilitate information and knowledge exchange, coordinated policy development, as well as regional and business development. The consortium comprised 36 partners from 11 Baltic Sea region countries including national and regional authorities, chambers of agriculture and industry and research institutions. The operation was financially supported from 2009 until 2011. Thereafter, the project was extended for additional two years (2012-2014) with a smaller group of 13 partners. More information can be obtained from the project website http://www.bioenergypromotion.net

${ }^{2}$ Many bioenergy pathways achieve considerable lifecycle GHG emission savings compared to the use of fossil fuels. GHG savings for solid biomass pathways are in general above 60 per cent both for power and heat produced. Some pathways are able to achieve savings above 80 per cent, particularly where local or regional forest or agriculture residues are used. Lower savings can occur for pathways based on long-distance biomass transports, on short-rotation coppice, in cases of high fertiliser use in agriculture or when fossil fuels are used for process energy [7]. Transport distances, cultivation inputs, process energy requirements and energy conversion efficiencies are the main parameters determining the final result. In some cases carbon savings can be low or even negative. This risk is particularly high where forests, peat land or other carbon rich land like permanent pasture/grassland are converted for the production of dedicated energy crops which in addition require high input of fertilizers and pesticides.
} 
bination with co-firing in large power plants based on fossil fuels. The consortium rather supported local and regional use of biomass. Furthermore, like imports of fossil fuel, biomass imports carry their own risks of insecurity. It should also be considered that demand for RES including biomass might increase in the exporting countries in the future.

In this context, the consortium acknowledged that co-firing of biomass might be a low cost and efficient way to reduce GHG emissions from electric power production, but should be viewed critical from a resource efficiency and energy efficiency perspective, particularly if this implies long distance transports of biomass and inefficient conversion processes with no or limited use of surplus heat. Yet at the same time, efficient utilization of surplus heat in small to medium scale dedicated biomass plants and cogeneration processes can contribute to the decarbonisation of both the heat and electricity sector. The consortium also considered that co-firing of biomass in conventional power plants would complicate the transition to a more distributed and flexible energy system [8].

The most promising bioenergy routes from a Sustainable Development perspective were regarded those that use locally available biomass residues from forestry and agriculture, processed residues and by-products from related industries, biogenic waste streams, and which employ highly efficient biomass conversion technologies and processes (e.g. co-generation processes). Wastes and by-products are currently underused, but can contribute significantly to reaching EU bioenergy targets. Hence, further effort is needed to facilitate exploitation of the large EU waste and residue potentials [9].

The consortium also emphasized the need to support minimum energy conversion efficiencies by referring to Article 13.6 of the Renewable Energy Directive (2009/28/EC), according to which Member States shall promote biomass conversion technologies that achieve conversion efficiencies of at least 85 per cent for residential and commercial applications and at least 70 per cent for industrial applications.

BIOENERGY PROMOTION stands out particularly by its emphasis on resource efficient and energy efficient bioenergy production and use. The partners emphasized that biomass is a limited natural resource and should therefore be used as efficient as possible. The consortium suggested promoting resource efficient biomass uses, including integrated and multi-functional bioenergy systems, biomass cascading, bio-refining or agricultural/forest/industrial symbiosis approaches. Finding resource efficient combinations of biomass sources, conversion technologies and energy end uses can be regarded as the main challenge for the further development of EU bioenergy production in an environmental perspective [9].

The following chapter includes a description of the recent EU policy developments with regard to biomass sustainability and concludes with an appraisal taking into account the conclusions of BIOENERGY PROMOTION.

\section{EU Policy Framework Addressing Sustainability of Bioenergy}

Energy policy has been a major driver for European integration. However, for about 30 years European energy policy has been limited to the areas of nuclear energy and coal based on the European Coal and Steel Community (ECSC) and the European Atomic Community (EURATOM). Although the founding treaties of the EU did not assign any explicit competence to the EU in the area of energy, the EU increasingly developed energy policy measures on the grounds of other policy objectives (e.g. referring to the internal market, competition, or environmental protection).

The Treaty of Lisbon, which entered into force on 1 December 2009, introduced a specific and broad legal basis for European energy policy. Article 194 of the Treaty on the Functioning of the European Union (TFEU) ${ }^{3}$ contains four objectives of European energy policy. Hence, Union policy on energy shall aim, in a spirit of solidarity between Member States, to:

- ensure the functioning of the energy market;

- ensure security of energy supply in the Union;

- promote energy efficiency and energy saving and the development of new and renewable forms of energy; and

- promote the interconnection of energy networks.

The Lisbon Treaty also stipulates that corresponding policy measures shall not affect the right of the Member

\footnotetext{
${ }^{3}$ Consolidated versions of the Treaty on European Union and Consolidated version of the Treaty on the Functioning of the European Union Protocols - Annexes - Declarations annexed to the Final Act of the Intergovernmental Conference which adopted the Treaty of Lisbon, signed on 13 December 2007 - Tables of equivalences. Official Journal C 326, 26/10/2012, pp. 1-390.
} 
States to determine the conditions for exploiting their energy resources, their choice between different energy sources and the general structure of its energy supply except on environmental grounds (Article 194 of the TFEU). However, the European Union is influencing the energy mix of individual Member States indirectly, e.g. by setting ambitious targets for renewable energy sources (see below).

The Lisbon Treaty also contains explicit provisions referring to Sustainable Development. According to Article 3 of the Treaty of the European Union (TEU) the Union shall work for the sustainable development of Europe based on balanced economic growth and price stability, a highly competitive social market economy, aiming at full employment and social progress, and a high level of protection and improvement of the quality of the environment. Sustainable Development is also recognized as one of the specific policy goals of the EU in its external relations. Paragraph 5 of Article 3 states: "In its relations with the wider world, the Union shall uphold and promote its values and interests and contribute to the protection of its citizens. It shall contribute to peace, security, the sustainable development of the Earth, ... as well as to the strict observance and the development of international law, including respect for the principles of the United Nations Charter.”

\subsection{EU Climate and Energy Policy Targets up to 2050}

In March 2007 the Council of Ministers agreed on three climate and energy policy targets, also known as the “20/20/20" goals for 2020:

- a 20 per cent reduction of GHG emissions compared to 1990;

- a 20 per cent improvement in energy efficiency compared to forecasts for 2020;

- a 20 per cent share for renewable energy in the EU final energy consumption including a 10 per cent minimum target for renewable energy consumed in transport to be achieved by all Member States.

In 2009 the European Council endorsed the long term objective of curbing Europe's GHG emissions by 80 95 per cent compared to 1990 levels as part of necessary reductions by developed countries as a group. To outline the pathways to a low carbon future, the European Commission published roadmaps for resource efficiency, energy, transport and a low carbon economy.

In order to bridge the gap between the targets for 2020 and the long term targets for 2050, in October 2014 the European Council agreed on the climate and energy policy framework for 2030 [10]. A cornerstone of the new framework is the binding target to reduce GHG emissions by 2030 by at least 40 per cent compared to the 1990 level. This target shall ensure that the EU is on track towards meeting its long-term target of cutting GHG emissions by at least 80 per cent by 2050. The European Council also endorsed a renewable energy target of at least 27 per cent of final energy consumption by 2030 which is binding at EU level. Unlike the current renewable energy target this would not be translated into national targets. Instead, the Council agreed on a new governance framework based on national plans for competitive, secure and sustainable energy. The Council also endorsed an indicative target of 27 per cent energy savings to be reviewed in 2020.

The EU has not endorsed any biomass-specific policy targets. There is a target of 10 per cent renewable energy in transport to be reached by 2020, contained in the Renewable Energy Directive (2009/29/EC). The European Commission intends to limit the contribution made from first generation biofuels produced from food crops to 5 per cent in order to reduce global land conversion for biofuel production (see sub-chapter 3.3.1). In its Communication “A Policy Framework for Climate and Energy in the Period from 2020 to 2030" of 22 January 2014 [11], the Commission refrained from establishing new targets for renewable energy or the GHG intensity of fuels used in the transport sector or any other sub-sector after 2020. This intention can be partly traced back to the uncertainty about emissions from indirect land-use change associated with the production of biofuels and bioliquids.

\subsection{Use of Solid and Gaseous Biomass in the EU-State of the Art and Outlook}

Solid and gaseous biomass used for electricity, heating and cooling is the most important source of renewable energy in the EU and plays a key role in achieving the 2020/2030 renewable energy targets and the long-term decarbonisation goals by 2050. In 2012, biomass and biowaste accounted for about two-thirds of all renewable energy consumption in the EU. The consumption of biomass for heating and electricity in the EU has already significantly grown since 2005 and is expected to further increase from 86.5 million tonnes of oil equivalent (Mtoe) in 2012 up to 110.5 Mtoe in 2020, although its share of total final renewable energy consumption would decrease from 54 per cent to 45 per cent due to the faster deployment of other renewables. By the end of the 
decade, on the basis of current trend, biomass for energy is expected to be used mainly for heating (90.4 Mtoe), followed by electricity (20 Mtoe) [4].

While by 2020 the vast majority of the EU's solid biomass consumption will likely still be met through domestic supplies, imports from third countries are projected to grow by the end of the decade. The Commission forecasts a biomass supply gap of about 21.4 Mtoe equal to over 15 per cent of EU primary bioenergy supply in 2018. This is likely to be met by imports mainly from the US and Canada, followed by Russia, Ukraine and Belarus, and largely in the form of wood chips and densified biomass, e.g. wood pellets including torrefied pellets [4]. Biomass demand is projected to further increase up to 2030, including imports, which raises the question of sufficient supply of sustainable and cost-effective biomass for all uses in the EU (ibid.).

EU imports of wood pellets have grown from 2.7 million tonnes in 2010 up to 4.3 million tonnes in 2013. Conversions of large-scale coal fired power plants to wood (co-)firing in Europe led to an explosive growth of wood pellet exports from Canada and Southwest US. By 2020, EU wood pellet imports from third countries are expected to be in the range of 15 - 30 million tonnes (equal to about 6 - 12 Mtoe). The main market for these wood pellet imports is the industrial sector, i.e. large-scale co-firing and dedicated combined heat and power (CHP) installations (ibid).

\subsection{EU Legislation Addressing Sustainability Challenges of Bioenergy}

\subsubsection{Binding Sustainability Criteria for Biofuels and Bioliquids}

In general, sustainability concerns related to renewable energy are addressed by cross-cutting EU legislation. In other cases, like e.g. in the case of biofuels and bioliquids, the EU has developed energy-specific rules.

As a consequence of the global biofuel controversy of 2007 and 2008 [12] [13] the European Union included sustainability criteria for biofuels and bioliquids in the Renewable Energy Directive (2009/28/EC) which are binding for all Member States. Biofuels and bioliquids which do not meet those criteria cannot be counted towards the EU renewable energy targets and national renewable energy obligations or benefit from financial support. Those criteria include minimum lifecycle GHG savings of 35 per cent (50 per cent from 2017; 60 per cent for new installations from 2018) compared to fossil fuels. Furthermore, the raw material shall not be obtained from land with high carbon stock and from land with high biodiversity value. Production of agricultural raw material cultivated in the European Community has to comply with EU environmental requirements for agriculture and be in accordance with the minimum requirements for Good Agricultural and Environmental Condition. The criteria cover direct land use change, but not indirect land use changes (iLUC). Verification of compliance is mainly ensured through private certification systems [14].

In its proposal to amend the Renewable Energy and the Fuel Quality Directives of 2012 the Commission underlined its intention to limit global land conversion for biofuel production, to improve the GHG performance of biofuels used in the EU and to encourage a greater market penetration of advanced biofuels. The objective of the proposed amendments is to promote biofuels that will help achieving substantial GHG emission reductions, that do not directly compete with food and feed and are more sustainable at the same time while limiting the maximum contribution made from biofuels and bioliquids produced from food crops to 5 per cent of the 10 per cent renewable energy target applying to the transport sector [15]. The 5 per cent cap is presently under negotiation between the Council and the European Parliament. In its Communication "A Policy Framework for Climate and Energy in the Period from 2020 to 2030" of 22 January 2014 the Commission emphasized that biofuels produced from food-based feedstock should not receive public support after 2020 [11].

\subsubsection{Non-Binding Recommendations for Solid and Gaseous Biomass Used in Electricity, Heating and Cooling}

In February 2010 the Commission published the Report on Sustainability Requirements for the Use of Solid and Gaseous Biomass Sources in Electricity, Heating and Cooling, also known as the Biomass Report [16]. The Commission decided not to introduce binding criteria at the EU level but to leave the introduction of binding criteria for solid and gaseous biomass used in electricity, heating and cooling to the discretion of each Member State. The Commission provided non-binding recommendations to Member States that had already introduced or plan to introduce national biomass sustainability requirements. Member States shall ensure that sustainability criteria in almost all respects are the same as those for biofuels and bioliquids laid down in the Renewable Energy Directive. The report recommended developing an EU-wide harmonised GHG emissions calculation 
methodology to calculate lifecycle emissions. It also recommended that the GHG performance criterion should not be applied to wastes. To stimulate higher energy conversion efficiencies, Member States should in their support schemes for electricity, heating and cooling installations differentiate in favour of installations that achieve high energy conversion efficiencies, such as high efficiency cogeneration plants as defined under the Cogeneration Directive (2004/8EC). The Commission also recommended that sustainability schemes apply only to larger energy producers of $\geq 1 \mathrm{MW}$ thermal or $\geq 1 \mathrm{MW}$ electrical capacity.

While in the meantime about half of the EU Member States have adopted regulations promoting higher efficiency of bioenergy production (i.e. efficient combined heat and power production), only few Member States (Belgium, Italy, United Kingdom) have adopted GHG saving criteria for biomass used in electricity/heating, which appear broadly in line with the Commission's recommendations [4]. For the time being the United Kingdom (UK) can be regarded the only country to have decided to introduce sustainability criteria on the basis of the European Commission recommendations of February 2010 (EUROSTAT 2015). However, the governments of the Netherlands, Denmark and Belgium are also drafting legislation to ensure the sustainability of their biomass feedstock [17] [18].

After the Biomass Report of 2010 had been published, non-governmental organizations (NGOs), researchers, and industry proponents like the European Union of the Electricity Industry (EURELECTRIC), the European Biomass Association (AEBIOM) and the European Biogas Association (EBA) called for a binding sustainability framework on the European level, although with different motivations. Scientists and NGOs criticized the recommendations as insufficient [19], whereas industry proponents raised concerns about potential trade barriers and market distortions evoked by an increasing number of different, inconsistent national sustainability regimes in the EU [20] [21]. Furthermore, in a resolution addressing the 2030 framework for climate and energy policies the European Parliament asked the Commission to propose sustainability criteria for solid and gaseous biomass, taking into account lifecycle GHG emissions in order to limit the inefficient use of biomass resources [22].

In July 2014 the European Commission published an updated report on the sustainability of gaseous and solid biomass used for electricity, heating and cooling [4]. The Commission re-affirmed that for the time being it will not propose any binding sustainability requirements for solid and gaseous biomass on the Community level. It argued that current EU and national legislation is sufficiently binding to provide sustainable operation conditions. It recommended again that Members States who introduce sustainability criteria on a national level shall ensure that these in almost all respects are the same as those for biofuels and bioliquids laid down in the Renewable Energy Directive.

The Commission argued that while a number of knowledge gaps still exist, the vast majority of the biomass pathways used today in the EU for heat and power are considered to provide significant GHG savings compared to fossil fuels. At the same time, a number of biomass routes can lead to negligible or negative GHG savings or other sustainability impacts. According to the Commission, further research and analysis is needed to assess the future role of such pathways in the EU energy sector and to gain better information on overall biomass availability for the EU in the period post-2020 (ibid.).

The Commission also argued that a limited number of Member States have adopted broadly consistent sustainability schemes and no apparent internal market barriers have been identified thus far. Therefore, at this stage, the risk of market distortion caused by national sustainability regulations could be effectively managed through the existing EU tools on technical standards (ibid.).

The Commission emphasized its commitment to closely monitor the origin and the end-use of biomass in the EU through the reporting requirements under the Renewable Energy Directive, and other policy initiatives related to the bio-economy, with the view to take appropriate corrective action, if needed (ibid.). Furthermore, it is committed to conduct research and analysis, to identify good practices on the cascading use of biomass and to gain a better understanding of future biomass availability (ibid.).

The report considers GHG savings of at least 70 per cent compared to the fossil fuel comparators "good practice" for existing bioenergy installations. As the carbon intensity of energy is projected to decrease in the future, higher GHG emission savings thresholds could be set for post-2020 in order to promote higher carbon savings, technology innovation, and best practices in feedstock production (ibid.)

In the report the Commission also announced to develop an improved biomass policy for the post-2020 period in order to maximise the climate and resource efficiency benefits of biomass in the wider bio-economy, while delivering robust and verifiable GHG emission savings and minimising the risks of unintended environmental impacts (ibid.). This is in line with the Communication "A policy framework for climate and energy in the pe- 
riod from 2020 to 2030” in which the Commission conceded that an improved biomass policy will be necessary to maximise the resource efficient use of biomass in order to deliver robust and verifiable GHG savings and to allow for fair competition between the various uses of biomass resources in the construction sector, paper and pulp industries and biochemical and energy production. This should also encompass the sustainable use of land, the sustainable management of forests in line with the EU forest strategy and address indirect land use effects as with bio fuels [11].

In its recently adopted Energy Union Strategy, the Commission committed itself to propose a new Renewable Energy Package in 2016-2017 which will include a new policy for sustainable biomass and biofuels as well as legislation to ensure that the 2030 EU target is met cost-effectively [23].

\subsection{Appraisal of EU Biomass Sustainability Legislation}

- Postponing the decision about binding biomass sustainability criteria does not reduce the level of uncertainty for investors who need to have a clear perspective on regulatory developments beyond 2020 when making investment decisions today.

- The current EU policy addressing bioenergy sustainability lacks coherence. The EU should develop a comprehensive and consistent sustainability framework in order to ensure a level playing field for all biomass applications and to progressively develop a coherent and ambitious set of sustainability criteria for all biomass uses across heat, electricity, transport, chemical industry, but also food, fodder and other bio-based products. A Knowledge-Based Bio-Economy where the same raw material including wastes, residues and other feedstock will be used increasingly for different end uses requires clear regulations and minimum standards which apply to all uses of biomass. In this context, the proposals to develop a "Biomass Framework Directive” [24] or a "Bioresources Directive" [25] appear rather convincing.

- The EU lacks a comprehensive vision of its future biomass supply and consumption both for energy and nonenergy uses. Such a vision should be based on reducing the need for bioenergy, using biomass resources efficiently and on ensuring a balance between overall biomass demand and sustainable supply.

- It can be regarded a promising signal that the Commission obviously raised its level of ambition regarding the GHG performance of bioenergy pathways compared to the first Biomass Report of 2010 which proposed the same GHG saving target as for biofuels (only 35 per cent).

- It is likewise positive that the importance of resource efficient use of biomass is increasingly reflected in recent EU policy documents.

- The resilience and enforcement of sustainable forest management legislation varies considerably in Europe. National legislation needs to adequately address specific risks of intensified production and harvesting methods related to forest biomass. Sustainable maximum cutting levels, whole tree harvesting, harvesting on steep slopes, stump extraction, removal of logging residues (e.g. tops, branches, foliage) and removal of deadwood should deserve particular attention. Monitoring, implementation and enforcement of forest legislation should be ensured.

- It is questionable whether existing governance mechanisms for sustainable forest management in biomass exporting countries are sufficiently robust and effective ${ }^{4}$ [26] [27].

- Trans-continental transport of wood pellets and ultimate co-firing in inefficient fossil power plants should not be promoted. Minimum conversion efficiency requirements for fossil and renewable energy plants would safeguard against developing bioenergy options that are efficient in reducing GHG emissions but still inefficient in terms of resource use. Instead, efficient utilization of surplus heat in small to medium scale cogeneration processes can contribute to the decarbonisation of both the heat and electricity sector [9].

\section{Policies and Measures in the Member States-The Examples of Germany and Poland}

Under BIOENERGY PROMOTION the partners prepared a number of country policy assessment reports based on in-depth analyses of national bioenergy policy frameworks and support schemes ${ }^{5}$. The key rationale of those assessments was to examine to what extent national policy frameworks and support schemes for solid and gase-

\footnotetext{
${ }^{4}$ Environmental NGOs from both the U.S. and Europe criticize non sustainable harvesting practices in exporting countries including clear cuts of carbon-rich and biodiverse forests for wood pellet production in the Southwest of the US [26] [27].

${ }^{5}$ The corresponding country policy assessment reports were published online (cf. http://www.bioenergypromotion.net)
} 
ous biomass integrate sustainability considerations. This chapter presents updated findings of the policy assessments conducted in Germany and Poland. In both countries flawed policies and misplaced incentives led to undesirable developments which became a matter of controversial public debate. The German case examines the use of energy crops (maize) for biogas production, whereas the Polish case refers to co-firing of biomass in coal fired power plants. The section will also describe how support schemes were re-adjusted in order to address sustainability risks and mitigate negative side effects.

\subsection{Germany}

\subsubsection{Policy Targets and Support Schemes}

Following the nuclear disaster in Fukushima in 2011, the federal government decided to initiate a long-term transformation of the entire energy system, also known as the Energiewende. This decision includes phasing out nuclear power by 2022. Table 1 contains an overview of further climate and energy policy targets of the federal government.

Electricity from RES is mainly supported through feed-in tariffs and feed-in premiums regulated by the Renewable Energy Sources Act (EEG). The Act entered into force in 2000 and was continuously amended in 2004, 2008, 2012 and 2014. On 1 August 2014 the latest amendments took effect, representing a fundamental overhaul of the existing support scheme. By 2017 at the latest, the support system will be replaced by competitive bidding procedures ${ }^{6}$.

Renewable heating and cooling is promoted by the Renewable Energies Heat Act (EEWärmeG), the Market Incentive Programme (MAP) governed by the Federal Office of Economics and Export Control (BAFA) and low-interest loans offered via the state owned promotional bank Kreditanstalt für Wiederaufbau (KfW) —see Table 2. In addition, support schemes are available for renewable heat on federal state (Länder) level. Renewable energy in transport is mainly supported by a quota system and through fiscal incentives.

Table 1. Selected climate and energy policy targets of the federal government in Germany and status quo in 2012.

\begin{tabular}{|c|c|c|c|c|c|}
\hline \multirow{2}{*}{ Sector } & \multirow{2}{*}{2012} & \multicolumn{4}{|c|}{ Target values } \\
\hline & & 2020 & 2030 & 2040 & 2050 \\
\hline $\begin{array}{l}\text { Reduction of GHG emissions compared } \\
\text { to } 1990 \text { level }\end{array}$ & $-24.7 \%$ & At least $-40 \%$ & At least $-55 \%$ & At least $-70 \%$ & $\begin{array}{l}\text { At least }-80 \% \text { to } \\
\quad-95 \%\end{array}$ \\
\hline $\begin{array}{l}\text { Renewable energy share in gross final } \\
\text { energy consumption }\end{array}$ & $12.4 \%$ & $18 \%$ & $30 \%$ & $45 \%$ & $60 \%$ \\
\hline $\begin{array}{l}\text { Renewable energy share in gross final } \\
\text { energy consumption for electricity }\end{array}$ & $23.6 \%$ & At least 35\% & $\begin{array}{c}\text { At least } 50 \% \\
\text { (2025: } 40 \%-45 \%)\end{array}$ & $\begin{array}{c}\text { At least } 65 \% \\
\text { (2035: } 55 \%-60 \%)\end{array}$ & At least $80 \%$ \\
\hline $\begin{array}{l}\text { Renewable energy share in gross final } \\
\text { energy consumption for heating/cooling }\end{array}$ & $11.1 \%$ & $14 \%$ & & & \\
\hline $\begin{array}{l}\text { Renewable energy share in gross final } \\
\text { energy consumption for transport }\end{array}$ & $6.9 \%$ & $10 \%$ & & & \\
\hline $\begin{array}{l}\text { Reduction of primary energy } \\
\text { consumption (compared to 2008) }\end{array}$ & $-4.3 \%$ & $-20 \%$ & & $-50 \%$ & \\
\hline $\begin{array}{l}\text { Share of electricity generation from } \\
\text { combined heat and power plants }\end{array}$ & $17.3 \%$ & $25 \%$ & & & \\
\hline Final energy productivity & $\begin{array}{l}1.1 \% \text { p.a. } \\
(2008-2012)\end{array}$ & \multicolumn{4}{|c|}{ 2.1\% p.a. (2008-2050) } \\
\hline $\begin{array}{l}\text { Annual building renovation rate in per } \\
\text { cent of the total building stock }\end{array}$ & Approx. 1\% & \multicolumn{4}{|c|}{ Doubling to $2 \%$ p.a. } \\
\hline Number of electric vehicles & 10,078 & 1 million & 6 million & & \\
\hline
\end{tabular}

Source: Progress Report [28].

\footnotetext{
${ }^{6}$ The new Guidelines on State Aid for Environmental Protection and Energy 2014-2020 (2014/C 200/01) adopted by the European Commission in April 2014 envisage the gradual replacement of feed-in tariffs and premiums by competitive bidding processes. The purpose is to increase cost effectiveness and limit market distortions. A pilot phase in 2015 and 2016 would allow Member States to test competitive bidding procedures in a small share of their new electricity capacity. From 1 January 2017, operating aid to renewable energy shall in principle be granted in a competitive bidding process.
} 
Table 2. Key support schemes for bioenergy in Germany.

\begin{tabular}{lll}
\hline Sector & Measure & Details \\
Electricity & $\begin{array}{l}\text { Renewable Energy Sources } \\
\text { Act (EEG) }\end{array}$ & $\begin{array}{l}\text { Feed in tariffs and feed in premiums guaranteed for 20 years depending on the plant } \\
\text { size; special remuneration rates for biowaste and manure; transition to competitive } \\
\text { bidding procedures from } 2017\end{array}$ \\
Heat & $\begin{array}{l}\text { Renewable Energies Heat Act } \\
\text { (EEWärmeG) }\end{array}$ & $\begin{array}{l}\text { Renewable heat obligation for new buildings and public buildings under major } \\
\text { renovation }\end{array}$ \\
Heat & $\begin{array}{l}\text { Market Incentive Programme } \\
\text { (MAP) }\end{array}$ & $\begin{array}{l}\text { Investment grants for small scale/individual RES based heating systems }+ \text { reduced } \\
\text { interest loans for larger scale RES based heating systems, RES based DH/C networks } \\
\text { and storage systems }\end{array}$ \\
& $\begin{array}{l}\text { Federal Immission Control Act } \\
\text { BImSchG) }\end{array}$ & $\begin{array}{l}\text { Renewable transport quota system (since 2015 based on GHG emissions); tax } \\
\text { exemptions and tax relief for certain biofuels }\end{array}$ \\
& Energy Tax Act (EnergieStG) &
\end{tabular}

Source: compiled by the author.

\subsubsection{Implementing the EU Sustainability Requirements for Biofuels and Bioliquids}

Germany was a frontrunner in establishing sustainability criteria for biofuels and bioliquids and the first Member State to transpose and implement the EU sustainability criteria for biofuels and bioliquids through the Biofuels Sustainability Ordinance (Biokraft-NachV) and the Biomass-Electricity Sustainability Ordinance (BioStNachV). Until 2012 the German Federal Ministry of Food, Agriculture and Consumer Protection via the Agency for Renewable Resources (FNR) provided financial support to the development of the International Sustainability and Carbon Certification (ISCC) system. In July 2011, the European Commission recognized ISCC as one of the first certification schemes to demonstrate compliance with the sustainability requirements for biofuels and bioliquids under the Renewable Energy Directive. Additionally, the system ISCC PLUS was developed for food, feed, technical/chemical and bioenergy applications (e.g. solid biomass).

\subsubsection{Addressing Environmental and Social Sustainability Risks of Biogas}

At the European level, the German government supported the extension of the binding EU sustainability criteria for biofuels and bioliquids to other bioenergy carriers [29]. The Government also plays an active role in several international bodies and initiatives addressing sustainability of bioenergy, particularly the Global Bioenergy Partnership (GBEP). However, so far the Government did not take any further steps to set up any binding sustainability scheme for solid and gaseous biomass on the basis of the EU Commission's recommendations.

To ensure sustainable bioenergy production and consumption, the Federal Government relies mostly on sector regulations (e.g. environmental legislation, nature conservation legislation, forest legislation, environmental Cross compliance rules in agriculture). However, as the example of using maize for biogas production illustrates, these regulations do not automatically prevent undesirable and unsustainable developments, also due to loopholes and lack of enforcement.

The number of biogas plants has increased considerably in Germany since 1992-see Figure 1. According to the German Biogas Association in 2014 the number of biogas plants reached 7944 including 153 biomethane injection plants. The installed electric capacity including electricity from biomethane reached $3859 \mathrm{MW}$ [30]. Annual installation rates were particularly high between 2004 and 2006 (on average 583 plant installations per year) and 2009-2011 (on average 1095 plant installations per year) [31]. One of the key drivers for the rapid development was the introduction of a special premium for using renewable raw material (energy crops) in 2004.

The dominant feedstock currently used in biogas plants is energy crops accounting for $80 \%$ of the energy supply from biogas with silage maize being the most important crop [32].

The growing cultivation and use of dedicated energy crops (particularly maize) for biogas production came under severe public criticism in recent years. The main reasons are adverse effects for visual landscape and increasing environmental problems like reduced crop variety and insufficient crop rotations, soil erosion and compaction, humus depletion, nitrate leaching, conversion of permanent grassland into arable land even in protected areas, losses of agricultural biodiversity, an increased risk of attack by pests and growing transport volumes for transporting raw material and fermentation digestate. Many of these effects have been acknowledged by the Government in its recent progress report pursuant to Article 22 of Directive 2009/28/EC on the promotion of the use of energy from renewable sources [28]. 


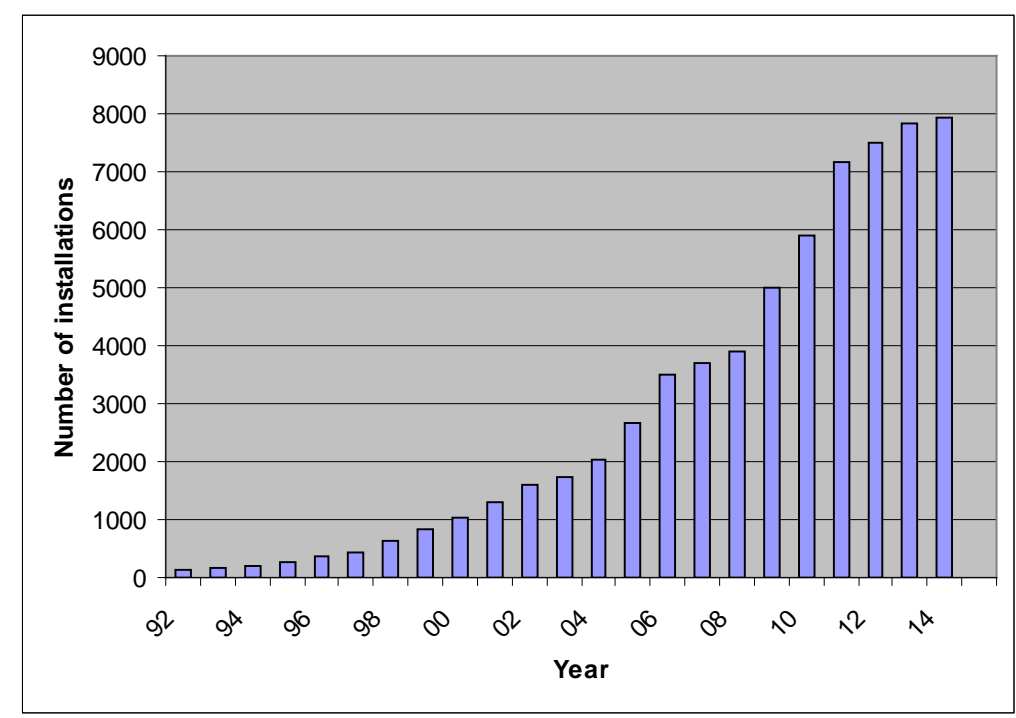

Figure 1. Development of biogas installations in Germany 1992-2014. Source: Fachverband Biogas:

http://www.biogas.org/edcom/webfvb.nsf/id/DE_Branchenzahlen.

Particularly in areas with a high share of animal husbandry a significant increase in maize production for biogas led to a growing competition between food, fodder and energy feedstock production and contributed to sharp price increases for agricultural land. In several regions of Lower Saxony the cultivation of maize requires more than half of the agricultural land (ibid.).

There is evidence that the Cross Compliance rules which, inter alia, aim at preserving permanent grassland, face loopholes and implementation deficits, partly failing to avoid unsustainable developments on a local scale. The growing cultivation of (energy) maize in Germany led to an increasing conversion of permanent pasture into arable land. A study by the Johann Heinrich von Thünen Institute [33] analyzing the utilization of agricultural land in four exemplary federal states concluded that between 2005 and 2007 these states faced a loss of permanent grassland of 80,000 hectares. This loss can be partly attributed to biomass production for energy (particularly energy maize). Conversion of permanent pasture was observed even in protected areas or on wetlands.

Another drawback was that in the beginning the support scheme did not encourage the efficient use of surplus heat from electricity production.

Hence, social and political acceptance for biogas production based on dedicated energy crops like maize has been continuously decreasing during the last years and the Government and also several federal states took measures to re-adjust existing support schemes in order to address the undesirable developments described above and reduce environmental and social sustainability risks.

With the amendments to the Renewable Energy Sources Act taking effect in 2012 and 2014 the Federal Government mainly intended to make electricity from RES more cost-effective and to improve their market and system integration. Remuneration rates for biomass were generally reduced. Furthermore, the law was re-adjusted in order to address environmental and social risks of renewable energy, particularly biogas production based on energy crops. The following changes were introduced in order to improve resource efficiency and energy efficiency of biogas systems and to avoid land use conflicts and negative environmental impacts:

- The utilization of maize as input material was stepwise limited since 2011. A ceiling of 60 per cent (by weight) was introduced for the use of maize and grain to prevent their excessive cultivation and foster greater diversification of substrates. Until 2014, the use of maize and other dedicated energy crops including cereals, fodder beet, sugar beet, or grass were still eligible for a special premium in the amount of 4 - $6 € \mathrm{ct} / \mathrm{kWh}$ paid on top of the basic remuneration.

- The amendments of 2012 gave more weight to the use of organic residues compared to the use of dedicated energy crops and encourage the use of ecologically more beneficial substrates. New premiums for using liquid manure and biomass from landscape management were introduced already in 2009. From 2012, these 
premiums were extended to include other types of environmentally beneficial material including blooming strips, buffer strips, wildflower growth, poultry manure, and clover as catch crop from arable land or straw. Use of these substrates was eligible for a special premium in the amount of $6-8 € \mathrm{ct} / \mathrm{kWh}$.

- Since 2012 preferential remuneration rates for biowaste fermentation plants (14 - $16 € c t / k W h)$ and small scale biogas facilities (up to $75 \mathrm{kWel}$ ) which use at least 80 per cent liquid manure ( $25 € \mathrm{\epsilon t} / \mathrm{kWh}$ ) applied.

- The amendments of 2012 replaced the "CHP bonus", a premium for using surplus heat from electricity production, by a general energy efficiency requirement. Biogas plants only qualified for support if at least 60 per cent of the heat produced was used, or the facility was operated using 60 per cent or more of slurry, or the electricity was sold directly.

The recent amendments of 2014 mark a turnaround not only for the biogas sector [34], but for the entire bioenergy sector in Germany. These amendments considerably reduce remuneration rates for biomass and impose further restrictions for bioenergy. They have to be seen in light of increasing cost and market orientation guiding renewable energy support and aim to mitigate the financial burden for electricity customers by curtailing support for more expensive electricity-generating systems including biomass based systems. Environmental rationales, particularly the intention to prioritize the use of organic waste and residues and further limit the use of food crops for biogas were underpinning the amendments.

Below we describe key provisions referring to biomass and biogas introduced in 2014:

- For the first time, growth corridors and flexible ceilings ${ }^{7}$ for the annual expansion of different renewable energy technologies were imposed. For biomass, a flexible ceiling of $100 \mathrm{MWel} / \mathrm{year}$ applies for newly installed capacity. Compared to the ceilings for photovoltaic systems (2500 MW) and wind onshore systems (2500 MW) the 100 MW ceiling for biomass is by far the most stringent one, taking into account previous average annual installation rates which reached 800 MWel in 2011 for biogas only.

- The previous, rather complex support structure with basic remuneration rates and supplementary premiums depending on plant size, feedstock and conversion technology was simplified. Now, there is only a basic remuneration in the range of 5.85 to $13.55 € \mathrm{ct} / \mathrm{kWh}$ depending on the plant size which applies in principle to all plants using biomass, regardless of feedstock or conversion technology. Previous premiums for specific raw material categories were abolished including the premium for environmentally beneficial input material and that for using dedicated energy crops like maize.

- Preferential remuneration rates exceeding the basic remuneration apply only in two cases: For small-scale biogas systems (up to $75 \mathrm{kWel}$ ) using manure, the feed-in tariff is $23.73 € \mathrm{ct} / \mathrm{kWh}$, if these systems use at least 80 mass per cent of manure and if they operate in cogeneration mode-see Table 3. Furthermore, plants digesting biowaste are eligible for a preferential remuneration between $15.26 €_{\mathrm{ct}} / \mathrm{kWh}$ (up to 500 $\mathrm{kWel}$ ) and $13.38 € \mathrm{ct} / \mathrm{kWh}$ (up to $20 \mathrm{MWel}$ ).

- As a general rule, direct marketing of renewable electricity was made mandatory for new renewable energy plants.

\begin{tabular}{lc}
$\begin{array}{l}\text { Table 3. Remuneration rates for electricity from biomass and biogas } \\
\text { in } 2014 .\end{array}$ \\
\hline Rated electric power $\left(\mathrm{kW}_{\mathrm{el}}\right)$ & Remuneration $(\mathrm{ct} / \mathrm{kWh})$ \\
\hline$\leq 150$ & 13.66 \\
$\leq 500$ & 11.78 \\
$\leq 5000$ & 10.55 \\
$\leq 20,000$ & 5.85 \\
$\leq 500$ (biowaste plant) & 15.26 \\
$\leq 20,0000$ (biowaste plant) & 13.38 \\
$\leq 75$ (biogas plant based on liquid manure) & 23.73 \\
\hline
\end{tabular}

Source: Renewable Energy Sources Act—EEG (21.07.2014).

\footnotetext{
${ }^{7}$ The amended Renewable Energy Sources Act stipulates that from 2016 feed in tariffs are subject to a quarterly digression of $0.5 \%$ to account for future cost reductions. The concept of "flexible ceilings" means that if the annual installed capacity exceeds the $100 \mathrm{MW}$ threshold a higher digression rate of $1.27 \%$ applies until the target corridor is reached again.
} 
The amendments of 2011 and particularly of 2014 led to a considerable slowdown of the market. The reduced remuneration rates and the flexible ceiling negatively affected the economical attractiveness of new investments in biogas. Annual installation rates sharply dropped from $800 \mathrm{MW}_{\mathrm{el}}$ in 2011 to $255 \mathrm{MW}_{\text {el }}$ in 2012, $158 \mathrm{MW}_{\text {el }}$ in 2013 and $136 \mathrm{MW}_{\mathrm{el}}$ in 2014 [30] [35] [36]—see Table 4. For 2015, the German Biogas Association expects an installation rate of only $8 \mathrm{MW}_{\mathrm{el}}[30]$.

The amendments pose a serious challenge to the German biogas sector which experiences a period of stagnation and further market consolidation. Several German plant manufacturers like AC Biogas GmbH or MTEnergie GmbH filed for insolvency, others seek to diversify their business portfolio and to unlock new export markets. According to the German Biogas Association, the number of employed persons in the sector dropped from roughly 63,000 in 2011 to 41,000 in 2013 [35].

Experts of the German Biomass Research Centre (DBFZ) criticized the recent amendments for being too restrictive, even from a sustainability point of view. The new remuneration rates are considered too low, therefore, installation rates are anticipated to remain even below the ceiling of $100 \mathrm{MW}_{\mathrm{el}}$. Market growth can only be expected for biowaste digestion and small scale biogas plants using liquid manure. The scientists argue that the reduced remuneration rates do not allow to fully exploit the sustainable biomass potential which mainly comprises animal excrements, agricultural residues and by-products like catch crops or straw. (Co-)fermentation of agricultural waste and residues is not considered cost-effective with the new support rates which negatively affects the utilization of animal excrements. The researchers also argue that the recent amendments jeopardise technology development and efficiency improvements [37].

Despite the remarkable market contraction, there are some promising developments which might contribute to a partial recovery of the biogas sector. The new German Circular Economy Act (KrWG) that transposes the European Waste Framework Directive (2008/98/EC) makes separate biowaste collection from households mandatory by 2015. Up to four million tonnes of household and kitchen waste might be additionally collected and fermented [30] [36].

\subsection{Poland}

\subsubsection{Policy Targets and Support Schemes}

Polish energy policy is mainly shaped by economy and tradition. In 2012, coal constituted 55 per cent of Poland's total primary energy consumption with the remainder represented by oil (26 per cent), natural gas (15 per cent) and renewable energy sources (RES) (4 per cent). For many years coal-firing plants produced 75 per cent or more of electric energy utilized in the country. In 2013, 11.3 per cent of electric energy was produced using RES (5.2 per cent from biomass-mainly co-fired with coal, 4.0 per cent from wind farms and 1.6 per cent from hydroelectric power stations).

Table 4. Selected statistics on the biogas sector in Germany 2011-2015.

\begin{tabular}{|c|c|c|c|c|c|}
\hline & 2011 & 2012 & $2013^{*}$ & $2014^{* *}$ & $2015^{* *}$ \\
\hline $\begin{array}{l}\text { Number of biogas plants } \\
\text { (thereof biomethane injection plants) }\end{array}$ & 7180 (77) & 7500 (109) & 7850 (144) & 7944 (153) & 8005 (156) \\
\hline Number of additional installations per year & 1270 & 340 & 335 & 94 & 61 \\
\hline $\begin{array}{l}\text { Installed electric capacity including } \\
\text { electricity from biomethane injection (MW) } \\
\text { (capacity relevant for electric work) }\end{array}$ & 3100 & 3350 & 3543 (3510) & 3859 (3646) & 4054 (3654) \\
\hline $\begin{array}{l}\text { Additional electric capacity of new } \\
\text { installations per year (MW) (relevant } \\
\text { for electric work) }\end{array}$ & 806 & 255 & 158 & 136 & 8 \\
\hline Annual generation of electricity (TWh) & 19.1 (net) & 22.8 (net) & 26.42 (gross) & 27.55 (gross) & 27.88 (gross) \\
\hline $\begin{array}{l}\text { Households supplied with electricity from } \\
\text { biogas (million) }\end{array}$ & 5.5 & 6.5 & 7.5 & 7.9 & 8.0 \\
\hline Share in total electricity generation (\%) & 3.2 & 3.9 & 4.1 & & \\
\hline Jobs & 63,000 & 45,000 & 41,000 & 41,000 & 39,000 \\
\hline
\end{tabular}

*Data based on extrapolation; ${ }^{* *}$ Data based on an expert survey; Source: Data published by Fachverband Biogas e.V. [30] [35] [36]. 
Poland's national target of 15 per cent of renewable energy in final energy consumption to be reached by 2020 results from a compromise between EU aspirations to reach an overall 20 per cent share and conflicting interests of the domestic coal industry which has a strong lobby in Poland. The strong influence of the coal industry, the abundance of coal and the expectation of increasing energy prices as a consequence of growing shares of renewable energy in the energy balance, explain the government's general reluctance to environmental measures proposed by the European Union.

Table 5 gives an overview of Poland's current climate and energy policy targets. These targets are mainly formulated in the following policy documents:

- National Renewable Energy Action Plan, [38];

- Energy Policy of Poland until 2030, [39];

- Energy Policy of Poland until 2050 - draft ver. 0.2, [40].

The main objectives formulated by these strategic policy documents are to ensure security of energy supply, to limit energy price increases and to reduce GHG emissions. The moderate policy targets regarding future GHG emissions should be reformulated in view of the climate and energy policy framework for 2030 endorsed by the European Council in 2014 [10]. The European Council adopted, inter alia, a binding EU target of at least 40 per cent domestic reduction in GHG emissions by 2030 compared to 1990. The new framework also includes a 27 per cent target for renewable energy which is binding at EU level and an indicative target for energy efficiency (see subchapter 3.1). Besides, the Council ruled that a new reserve of 2 per cent of emission allowances under the EU Emissions Trading System will be set aside to address particularly high additional investment needs in low income Member States (GDP per capita below 60 per cent of EU average). The Polish Prime Minister [41] expects for Poland a corresponding amount of around 7.5 billion PLN (1.8 billion EUR). These new provisions are expected to promote a radical modernisation of the Polish energy sector.

After years of uncertainty a new renewable energy act was adopted by the Parliament on 20 February 2015 [42] which introduces new support mechanisms for electricity from RES. The existing support system based on renewable energy certificates (with changing values determined at the Polish Power Exchange) will be supplemented by a feed-in tariff system for small prosumer installations and a competitive bidding procedure (auctions) for installations with an electric capacity exceeding $40 \mathrm{kWe}$. After formal verification, successful bidders have to sell the electricity at the proposed price for the next 15 years which reduces investment risks.

The government will decide which amount of energy will be accepted for each auction. Separate auctions will be organized for installations with capacities in the range $40 \mathrm{kWe}-1 \mathrm{MWe}$ and those above 1 MWe. Also, special provisions apply for existing RES installations which wish to shift from the renewable certificate scheme into the new auction system.

The Government expects that the new support scheme will be more efficient and effective than the previous one. In the auctions, the lowest bids will be entitled to sell their electricity. However, the prices offered in the bids certain cannot exceed technology-specific reference prices calculated annually by the Polish Energy Regulatory Office (pl. Urząd Regulacji Energetyki).

The support for prosumers depends on plants capacity: for installations up to $3 \mathrm{kWe}$ the feed-in tariff equals 0.75 PLN for $1 \mathrm{kWh}$ supplied into grid during 15 years and for installation from 3 till $10 \mathrm{kWe}$ it equals 0.40 0.70 PLN for $1 \mathrm{kWh})$.

The support scheme will be financed through a newly introduced RES charge (pl. Opłata OZE) paid by all electricity customers. In 2015 the Ministry of Economy proposed a RES charge equal to 2.27 PLN/MWh (0.54 $€ / \mathrm{MWh})$.

The new regulations will likely help to develop a new model of distributed energy, i.e. the creation of local autonomous energy production centres, which enable savings and minimize transmission losses. It is also assumed that the new act will have positive employment effects (10,000 new jobs).

The new act will enter into force 30 days after its publication in the Polish Journal of Laws. However, the new auction scheme will enter into force on 1 January 2016.

\subsubsection{Implications of the New Renewable Energy Law for Biomass and Bioenergy Sustainability- The Case of Co-Firing Biomass in Fossil Power Plants}

Nowadays, about 40 per cent of renewable electric energy in Poland comes from co-firing in large installations and is eligible for RES support, although it faces strong criticism from experts in the field and among small energy producers (see e.g. Olszewski [43]). 
Co-firing of biomass and coal in big-scale power plants is reported to cause numerous problems, with respect to the process efficiency as well as regarding the sustainability advantage. Co-firing of biomass and coal in large-scale generation systems usually results in a reduction of the system efficiency (by a few percent on average) and problems with contamination of the installation. It can be assumed, that without significant revenues from the renewable energy certificates, co-firing would hardly be economically attractive. Biomass is often transported over long distances including from Brazil, Indonesia and Africa (ibid.) which reduces the lifecycle GHG savings. Besides, large scale power plants contribute to distort the biomass market, which jeopardizes the development of local, distributed energy systems which can be regarded as the most efficient way for utilization of renewable energy sources enabling regional economic development and regional value creation, and improving security of energy supply [44].

Unfortunately, despite these disadvantages biomass co-firing is financially supported in a number of European countries, and shall be supported in Poland until 2020 according to the Government's National Renewable Energy Action Plan (NREAP) [38]. However, the new OZE regulations [42] reduced the support for co-firing power plants by 50 per cent, with exception of a few new dedicated ${ }^{8}$ co-firing installations. Financial support will also be withdrawn in the case of co-firing high-quality wood ${ }^{9}$ (stem wood). Moreover, the NREAP envisages substitution of forest biomass by agricultural biomass and to curtailing financial support for co-firing technologies from other funding programmes (Structural Funds).

The new OZE regulations help to increase the share of renewable electricity to at least 25 per cent, particularly in installations with capacity below 1 MWe, which utilize local energy resources. The regulations also include provisions targeting sustainable production of biofuels and bioliquids as well as the protection of highquality wood.

Referring to biomass, the Polish NREAP [38] highlights the importance of sustainable forest management, biodiversity and efficient use of natural resources, such as soil, water and land. It also stipulates that the socialeconomic role of forests should not be lost out of sight. The "Polish Energy Policy until 2030" [39] considers utilization of local energy sources as the way to achieve higher energy efficiency and energy security. It emphasizes the social benefits of local energy and calls for better utilization of biowaste to increase resource efficiency. However, these claims have more declarative character and translation into action is pending.

\section{Corporate Sustainability Initiatives in the Field of Bioenergy}

Table 6 provides an overview of major European operators of biomass plants. In the absence of any binding EU

Table 5. Selected climate and energy policy targets in Poland and status quo in 2012.

\begin{tabular}{|c|c|c|c|c|}
\hline \multirow{2}{*}{ Sector } & \multirow{2}{*}{2012} & \multicolumn{3}{|c|}{ Target values } \\
\hline & & 2020 & 2025 & 2030 \\
\hline $\begin{array}{l}\text { Reduction of } \mathrm{CO}_{2} \text { emission compared to } \\
1990 \text { level }^{1}\end{array}$ & $29.1 \%{ }^{2}(\mathrm{GHG})$ & $-23.8 \%$ & $-19.9 \%$ & $-17.5 \%$ \\
\hline $\begin{array}{l}\text { Renewable energy share in gross final } \\
\text { energy consumption }^{1}\end{array}$ & $10.9 \%^{3}$ & $15 \%$ & $15.8 \%$ & $16 \%$ \\
\hline $\begin{array}{l}\text { Renewable energy share in gross final } \\
\text { energy consumption for electricity }\end{array}$ & $10.7 \%^{3}$ & $18.5 \%$ & $\begin{array}{c}19.5 \% \\
37.9 \mathrm{TWh} / 194.6 \mathrm{TWh}\end{array}$ & $\begin{array}{c}18.2 \% \\
39.5 \mathrm{TWh} / 217.4 \mathrm{TWh}\end{array}$ \\
\hline $\begin{array}{l}\text { Renewable energy share in gross final } \\
\text { energy consumption for transport }{ }^{1}\end{array}$ & $6.1 \%^{3}$ & $10 \%$ & & $10.4 \%$ \\
\hline $\begin{array}{l}\text { Reduction of primary energy consumption } \\
\text { (compared to 2006) }\end{array}$ & $-4.7 \%(2010)$ & $4 \%$ & $13.5 \%$ & $21.2 \%$ \\
\hline $\begin{array}{l}\text { Share of electricity generation from } \\
\text { combined heat and power plants }{ }^{1}\end{array}$ & $16.2 \%(2006)$ & & & $22 \%$ \\
\hline Primary energy intensity [toe/1000 PLN] ${ }^{1}$ & 0.048 & 0.0466 & 0.0386 & 0.033 \\
\hline
\end{tabular}

${ }^{1}$ Source: Energy Policy of Poland until 2030 [39]; ${ }^{2}$ Progress Towards Achieving the Kyoto and EU 2020 Objective [45]; ${ }^{3}$ Eurostat (2013) SHARES (Renewables) [46].

\footnotetext{
${ }^{8}$ Installations which are equipped with separated technological lines to supply biomass, bioliquid or biogas to the combustion chamber with an amount exceeding 20 per cent or fluidized bed installations with a capacity below 50 MW and which utilize at least 30 per cent energy from biomass, bioliquid or biogas

${ }^{9}$ Whole large-size trunks in three categories from $0.5 \mathrm{~m}$ above.
} 
Table 6. Major European operators of biomass plants 2013/2014 (incl. CHP).

\begin{tabular}{cccc}
\hline Biomass plant operator & Country & $\begin{array}{c}\text { Electrical capacity }\left(\mathrm{MW}_{\mathrm{el}} \text { in }\right. \\
\text { operation including CHP) }\end{array}$ & Biomass fuel used \\
\hline Drax Group plc. & UK & 1260 & Pellets \\
UPM/Pohjolan Voima Oy & Finland & 955 & Wood, black liquor, peat \\
E.ON & Germany & 783 & Pellets, wood chips \\
Fortum & Finland & 610 & Solid biomass, bio wastes, bio oil \\
Vattenfall & Sweden & 444 & Solid biomass, waste \\
Metso & Finland & 265 & Biomass co-firing \\
Electrabel/GDF Suez & Belgium & 260 & Wood chips \\
Veolia (Dalkia) & UK & 250 & Biomass co-firing \\
GDF Suez/Cofely & France & 223 & Biomass co-firing \\
DONG Energy & Denmark & 220 & CHP (wood chips, pellets, straw) \\
Kaukaan Voima Oy & Finland & 125 & CHP (wood, bark, stumps, forest residues, \\
\hline
\end{tabular}

Source: EurObserv’ER 2015 [49].

wide sustainability framework for solid and gaseous biomass used for electricity, heating and cooling production, energy utilities and other industry stakeholders started to develop voluntary biomass sustainability schemes. In early 2010, major European energy companies that co-fired wood pellets and wood chips in their thermal power plants or dedicated biomass plants formed the Initiative Wood Pellet Buyers, which in 2013 was transformed into the Sustainable Biomass Partnership (SBP). Most of the companies joining the SBP had own sustainability schemes and biomass procurement policies in place. Furthermore, several energy utilities or industry associations concluded voluntary agreements with national or regional governments to ensure sustainable biomass sourcing and bioenergy production. Sustainable procurement and use of biomass are also a growing concern for regional and local utilities—see Table 6.

In the frame of BIOENERGY PROMOTION 2, the project consortium examined a number of corporate biomass sustainability initiatives which are particularly relevant for the Baltic Sea region without intending to be exhaustive. The findings were published online [47]. In the following, we will present brief portraits of several major initiatives which contain updated information.

\subsection{The Sustainable Biomass Partnership (Formerly Initiative Wood Pellet Buyers)}

The Sustainable Biomass Partnership (SBP) is an industry-led sustainability initiative formed in 2013 by several major European utilities that use biomass, mostly in the form of wood pellets in large thermal power plants. SBP continues the work of the former Initiative Wood Pellet Buyers (IWPB) ${ }^{10}$ [48].

SBP involves the utility companies DONG Energy, Drax, E.ON, GDF Suez, HOFOR, RWE and Vattenfall. The objective of the SBP is to develop the tools necessary to ensure that solid biomass used for energy production by its member organisations, complies with regulations on sustainability and biomass legality, and that the sector is recognised as an exemplar of good practices [50]. The standards shall meet the various country specific criteria that have emerged or are currently under development, particularly in the UK, the Netherlands, Belgium and Denmark. The Partnership also facilitates the documentation and transfer of energy and GHG data along the supply chain to the end-user. Under the SBP Framework a biomass producer, typically a pellet mill, is certified by a SBP approved certification body and is responsible for ensuring that its feedstock meets the SBP standards [51].

In 2014, the SBP endorsed its draft Biomass Assurance Framework (BAF). According to the SBP, the BAF is

${ }^{10}$ IWPB was launched by GDF Suez, Vattenfall, DONG, Drax, RWE/Essent and E.ON joined the IWPB, together with four verification and certification companies and three wood pellet associations. IWPB initially aimed to develop a standard biomass trading agreement with a focus on wood pellet specifications, trading terms and sustainability criteria. Collectively, the IWPB (now SBP) members make up 70 percent of the European wood pellet market [48]. 
designed as a clear statement of principles, standards and processes necessary to demonstrate compliance with legal, regulatory and sustainability requirements. The BAF includes the following five standards:

- Sustainable feedstock standard

- Evaluation of feedstock against the sustainable feedstock standard

- Certification systems standard

- Chain of custody standard

- Energy and carbon data selection [50]-[52].

As a result of a public consultation process held in 2014, BAF Version 0.0 was released in June 2014 for final testing by certification bodies and biomass producers. SBP expects to launch version 1.0 in the first quarter of 2015. So far, SBP accepted six certification bodies as applicants which are progressing towards SBP-approved status.

SBP seeks to align the Biomass Assurance Framework with existing forest certification schemes like the Forest Stewardship Council (FSC) and the Programme for Endorsement of Forest Certification (PEFC) as far as possible. Yet SBP also argues that there is a limited uptake of certification in some key forest source areas, especially in the US and source areas based on small forest owners and that those certification systems do not cover all relevant requirements of biomass users (e.g. GHG accounting including forest carbon stock changes). Therefore, SBP aims to provide a mechanism for assessing and mitigating risk for biomass from non-certified sources as well through a specific risk assessment approach to be performed by the biomass producers (e.g. pellet plants).

The SBP can be regarded as a promising initiative, although it primarily reflects the interests of the traditional energy industry. One of the key rationales behind the initiative is to alleviate co-firing of biomass in large-scale fossil power plants or their conversion to dedicated biomass plants. As we pointed out earlier (see chapter 2), the BIOENERGY PROMOTION consortium concluded that co-firing of biomass might be a low cost and efficient way to reduce GHG emissions from electric power production, but should be viewed critical from a resource efficiency and energy efficiency perspective, particularly if this implies long distance transport of biomass and there is no or low use of surplus heat. Taking into account the findings of BIOENERGY PROMOTION, another drawback of the BAF is that in its current version it does not formulate any minimum lifecycle GHG reduction target compared to the use of fossil fuels ${ }^{11}$.

\subsection{Sustainable Biomass Procurement Policies of Energy Utilities}

Prior to 2013, in Europe there were mainly three large-scale industrial wood pellet consumers for electric power production: Electrabel (Belgium), RWE Essent (the Netherlands, UK), and Drax (UK). All developed their own verification system for sustainable biomass, like, for example, the Green Gold Label developed by Essent [3]. Other major energy utilities headquartered or operating in the Baltic Sea Region like E.ON [53], DONG Energy [48], FORTUM [54] and Vattenfall [55] endorsed own biomass procurement principles, guidelines and policies.

E.ON operates throughout Europe, Russia and North America. Use of biomass involves mainly operations in Sweden at a number of coal-fired power stations and dedicated biomass power plants across Europe. The company aims to convert some of its existing coal fired plants to dedicated biomass plants or to co-firing facilities. E.ON disposes of a Responsible Procurement Policy that lays out the minimum standards for the corporate social responsibility performance of the company's business partners, suppliers and their sub-contractors. For the procurement of biomass the company applies the Biomass Purchasing Amendment, which is in place since 2009 [53] and which is attached to all biomass procurement agreements [56]. The Biomass Purchasing Amendment lays out the conditions under which the company procures biomass for power generation. Accordingly, biomass use will be undertaken in such a manner as to significantly reduce GHG emissions relative to fossil fuels; the production process of biomass shall be designed in a way that relevant stakeholders are involved and that it contributes to the social and economic development of local, rural and indigenous peoples and communities, and it will not compete with food crops; and that production shall avoid negative impacts on biodiversity and that it

\footnotetext{
${ }^{11}$ Furthermore, responding to the public consultation organized by SBP in 2014, various environmental NGOs criticized, inter alia, the proposed BAF for being too vague. They also consider the risk assessment approach insufficiently credible and complain that the SBP dilutes the concept of sustainable forest management as no distinction is made between SBP, FSC and PEFC and no reward is given to companies opting for more ambitious standards like the FSC. Furthermore, it is argued that in its current version the BAF reveals severe flaws as, for example, it fails to provide firm restrictions on sourcing wood from high conservation value forests, like e.g. species and carbon rich wetland forests in the US to produce pellets exported to EU markets [52].
} 
will not violate land rights.

To ensure compliance with the company's procurement policies, E.ON carries out risk reviews of all suppliers and joint venture partners, conducts audits locally and makes these guidelines an integral part of all contracts. E.ON can undertake internal or external audits and site visits to monitor and control the compliance with its Biomass Purchasing Amendment, and non-compliance with these standards can lead to sanctions.

In publicly available documentation the company does not disclose information on quantities, types or origin for its biomass supply (ibid.). Criteria were criticized for being too general and open to interpretation. Verification was criticized by for not being sufficiently independent [57].

The Finnish utility Fortum operates in the Nordic and Baltic countries, Poland, Russia and the UK. In 2014, one per cent of the company's total electric power production was based on biomass [58]. The utility utilizes, inter alia, wood chips, other wood-derived fuels and bioliquids for combined heat and power and heat-only production. In 2013, 95 per cent of the biomass used by Fortum consisted of wood pellets, wood chips and industrial wood residues that originated from Finland, Sweden and Estonia. Other types of bioenergy carriers were acquired from Brazil and Malaysia [59].

In 2011 the company endorsed its "Position and Actions to ensure sustainable use of bioenergy in its operations” [54]. Fortum's sustainability principles referring to bioenergy production include:

- Protection of biodiversity, carbon stock and environmental quality (air, soil, water);

- GHG emission savings compared to fossil fuels;

- Optimization of resource use efficiency;

- Social issues including human rights, labour rights, living conditions, land ownership.

According to the paper Fortum takes measures to verify the traceability and sustainability of biomass to ensure that purchased wood and wood products are legally logged and sourced. Bioenergy suppliers are requested to provide information on the origin of the bioenergy traded. To monitor compliance supplier audits shall be conducted by Fortum's own professionals or, if needed, by independent third parties. Fortum aims to certify its wood biomass supply chain and to increase the share of certified wood in the supply of wood from forestry in accordance with the forest certification schemes FSC, PEFC, corresponding global standards or national regulations [54]. Quantities, types and origin of bioenergy is monitored and disclosed in Fortum's sustainability reporting. In 2011, Fortum withdrew its membership in the Initiative Wood Pellet Buyers [60].

Vattenfall is one of the largest purchasers of biomass for power generation worldwide. More than 30 of the utility's heating and power plants are powered entirely or partially by biomass. However, currently only one per cent of Vattenfall's electricity production and 14 per cent of heat production is based on biomass [55]. The Vattenfall Group is operating in Sweden, Germany, Denmark, Finland and several Western European countries. The parent company, Vattenfall $\mathrm{AB}$, is fully owned by the Swedish state. A total of 3.4 million metric tonnes of biomass was used by Vattenfall in 2010 as feedstock for electricity and heat generation, around 50 per cent of which consisted of biogenic waste, sourced from municipalities and used mainly in plants in Sweden and Germany. Processed wood products such as pellets represent about 2 per cent of the biomass use, sourced mainly locally, according to the company. Before May 2012, the company also imported small amounts of wood chips from old rubber trees through the Liberian biomass company Buchanan Renewables for combustion in power stations. The company is planning to increase its biomass supply from Europe, North America and South America.

Vattenfall provides a certain degree of transparency regarding the type, source and origin of biomass. In publicly available documentation, such as corporate reports and websites the company discloses some information on the type and origin of biomass. Vattenfall uses a "Code of conduct for suppliers", which is based on the ten principles of the UN Global Compact as well as risk and impact assessments and audits and monitoring. Vattenfall is a founding member of the Sustainable Biomass Partnership. In 2012, Vattenfall Europe and the city state of Berlin concluded a voluntary agreement on the sustainability of biomass procurement valid from 2010 until 2020 (see sub-chapter 5.4).

The Danish company DONG Energy started to convert a number of coal- and gas-fired CHP plants to biomass or multi-fuel plants. By this, the utility aims to raise the share of biomass in combined heat production from 28 per cent in 2014 to at least 40 per cent in 2016 and 50 per cent in 2020 [48]. Towards 2020, DONG Energy expects to double the annual consumption of wood pellets to approximately 1.8 million tonnes and to increase the annual consumption of wood chips from 0.3 million tonnes in 2013 to approximately 1.1 million tonnes in 2020 (ibid.). Recently, the utility endorsed an Energy Programme for Sustainable Biomass Sourcing (ibid) 
which closely refers to a recent industry agreement concluded by two industry associations in response to a request by the Government (see below). In its sustainable biomass sourcing programme, the utility discloses some information on the type and origin of biomass.

DONG Energy only purchases wood chips and wood pellets from suppliers who ensure that the biomass originates solely from forest areas where processes and initiatives have been implemented resulting in:

- Continuous reforestation

- Protection of the ecosystem and biodiversity

- Protection of particularly exposed areas or areas worthy of preservation

- Compliance with social and professional rights, including the UN's Universal Declaration of Human Rights.

Furthermore, the suppliers must meet DONG Energy's ethical, social and environmental requirements and document that the lifecycle GHG emission savings reach at least 70 per cent rising to 75 per cent in 2025.

The programme adheres to the requirements and certification system under the Sustainable Biomass Partnership in which DONG is a member (see above). In the future, DONG Energy's biomass supply shall be based on SBP-certified suppliers, once the SBP sustainability framework has been fully implemented.

Under the project BIOENERGY PROMOTION 2 other energy companies in the Baltic Sea Region and beyond were analysed, including EDF Polska, Dalkia, JSC Tukuma Siltums, JSC Komunālserviss TILDe, or Energinet.dk. However no explicit corporate biomass sustainability schemes, policies or programmes were identified.

\subsection{Voluntary Agreements between Energy Utilities, Public Authorities and/or Other Stakeholders}

\section{Biomass sustainability agreement in Denmark (2014)}

On December 4, 2014 the Danish Ministry of Climate, Energy and Building announced that the Danish energy association Dansk Energi and the Danish district heating association Dansk Fjernvarme signed a biomass sustainability agreement in response to an earlier request of the Minister Petersen to use only biomass for energy which was produced in a sustainable way. The voluntary industry agreement contains requirements on sustainable forest management and minimum lifecycle GHG emissions ${ }^{12}$. Subsequently, the utility DONG Energy endorsed a Programme for Sustainable Biomass Sourcing translating the agreement's provisions into the company's biomass procurement policy (see sub-chapter 5.2).

Agreement between the Senate of Berlin and Vattenfall Europe on sustainable procurement of woody biomass (2011) [61]

In Berlin, where Vattenfall is co-firing biomass in several combined heat and power plants, the company's biomass sourcing policy came under severe criticism from the public when Vattenfall announced plans to import substantial amounts of biomass stemming from non-productive rubber trees. This led to an intense public debate about the environmental and social sustainability risks of Vattenfall's biomass procurement policy. As a result, to ensure the sustainable procurement of woody biomass, in April 2011 Vattenfall signed an agreement with the Senate of Berlin on criteria for the sustainable procurement of woody biomass [61].

The agreement applies only to biomass used by Vattenfall Europe in power plants located in Berlin, but would be co-ordinated with voluntary standards used throughout Vattenfall. The agreement is valid from 20112020 and covers mainly environmental criteria including GHG savings and social criteria. The agreement includes criteria referring to:

- GHG reductions of 50 per cent compared to the use of coal;

- Biodiversity protection, protection of carbon stock, preservation of environmental quality (air, soil, water);

- Social issues referring to land use rights and labour legislation.

In the agreement the company committed itself to verify compliance with the sustainability criteria and every two years to carry out a third party assessment. Compliance shall principally ensured by certification systems, except for those cases when untreated wood residues from forestry or other origin are used.

The first assessment report pursuant to the agreement was published in 2013 [62]. The report which was verified by the auditing company KPMG concluded that in the reporting period 2011/2012 biomass traceability was ensured and Vattenfall fully met the sustainability criteria set out in the agreement. In 2011 and 2012, biomass was almost exclusively procured from local and regional sources, forest residues being the dominant source.

\footnotetext{
${ }^{12}$ Corresponding agreements between the Government and the energy sector were concluded in the Netherlands [18].
} 
Reportedly, environmental risks were avoided and no social risks identified. GHG emissions savings were 95 per cent compared to the use of coal which means that the minimum target value of 50 per cent was considerable overmatched.

Table 7 provides an overview of different biomass sustainability schemes and initiatives with their respective minimum lifecycle GHG saving requirements.

\section{Conclusions}

The paper presented updated findings from policy and corporate strategy analyses conducted in the frame of BIOENERGY PROMOTION, one of the flagship projects under the EU Baltic Sea Region Strategy. The overall purpose of this research was to examine how policy and business actors address environmental and social sustainability concerns of biomass.

In order to achieve the long term decarbonisation goals of the EU, the BIOENERGY PROMOTION consortium recommended supporting particularly those bioenergy pathways which achieve high lifecycle GHG saving compared to the use of fossil fuels. Furthermore, the operation stood out with its emphasis on resource efficient and energy efficient bioenergy production and use. Hence, policies promoting sustainable cultivation/harvesting/ sourcing of biomass need to be accompanied by measures that encourage efficiency improvements downstream the supply chain including logistics, conversion and final use of bioenergy (see also [9]).

Although many stakeholders including the European Parliament, energy utilities, industry associations, NGOs, researchers have been advocating binding EU sustainability criteria for solid biomass, in 2014 the European Commission re-affirmed its earlier decision not to introduce any binding sustainability scheme for solid and gaseous biomass before 2020. However, a Knowledge-Based Bio-Economy where the same biomass streams

Table 7. GHG saving requirements of selected sustainability schemes and initiatives covering the use of solid/gaseous biomass for electricity, heating and cooling.

\begin{tabular}{|c|c|c|c|}
\hline Category & Sustainability scheme/initiative & $\begin{array}{l}\text { Minimum GHG } \\
\text { savings (\%) }\end{array}$ & Fossil fuel comparator \\
\hline \multirow{2}{*}{$\begin{array}{l}\text { EU sustainability framework } \\
\text { for biofuels/bioliquids }\end{array}$} & $\begin{array}{l}\text { Renewable Energy Directive 2009/28/EC } \\
\text { (referring to biofuels and bioliquids) }\end{array}$ & $35 \%(50 \% / 60 \%)$ & EU fossil fuel comparator \\
\hline & $\begin{array}{l}\text { Proposal for a DIRECTIVE amending } \\
\text { Directive 98/70/EC and amending } \\
\text { Directive 2009/28/EC; COM (2012) } 595 \text { final }\end{array}$ & $\begin{array}{l}60 \% \text { for new installation } \\
\text { in operation from } 7 / 2014\end{array}$ & ${ }^{\mathrm{S}}$ EU fossil fuel comparator \\
\hline \multirow{2}{*}{$\begin{array}{l}\text { EU sustainability framework } \\
\text { for solid/gaseous biomass } \\
\text { used in electricity, heating } \\
\text { and cooling }\end{array}$} & Biomass Report COM (2010)11 & $35 \%$ & $\begin{array}{l}\text { EU-wide fossil fuel comparators } \\
\text { for different technologies }\end{array}$ \\
\hline & Biomass Report COM (2014)11 & $\begin{array}{l}70 \% \\
\text { (good practice) }\end{array}$ & $\begin{array}{l}\text { EU-wide fossil fuel comparators } \\
\text { for different technologies }\end{array}$ \\
\hline $\begin{array}{l}\text { National sustainability } \\
\text { schemes }\end{array}$ & UK Renewable Obligation & $\begin{array}{l}60 \% / 66 \% \\
72 \%(2020) \\
75 \%(2025)\end{array}$ & $\begin{array}{l}\text { EU wide fossil fuel comparator for } \\
\text { electricity }\end{array}$ \\
\hline \multirow{4}{*}{$\begin{array}{l}\text { Corporate sustainability } \\
\text { schemes and voluntary } \\
\text { agreements }\end{array}$} & Initiative Wood Pellet Buyers & $60 \%$ & Reference fossil fuels \\
\hline & $\begin{array}{l}\text { Agreement between the Senate of Berlin } \\
\text { and Vattenfall Europe }\end{array}$ & $50 \%$ & $\begin{array}{l}\text { Coal (taking into account the GHG } \\
\text { calculation methodology proposed } \\
\text { by the EU Commission) }\end{array}$ \\
\hline & $\begin{array}{l}\text { Green Deal on sustainability reporting of } \\
\text { solid biomass for energy between the Dutch } \\
\text { government and various energy companies }\end{array}$ & $60 \%$ & Reference fossil energy \\
\hline & $\begin{array}{l}\text { DONG Energy Programme for Sustainable } \\
\text { Biomass Sourcing }\end{array}$ & $\begin{array}{l}70 \% \\
75 \%(2025)\end{array}$ & $\mathrm{n} / \mathrm{a}$ \\
\hline \multirow[t]{2}{*}{ Project based initiatives } & $\begin{array}{l}\text { Biomass Futures } \\
\text { (Intelligent Energy Europe Programme) }\end{array}$ & $\begin{array}{l}55 \%(2015) \\
60 \%(2020) \\
75 \%(2030)\end{array}$ & Natural gas \\
\hline & $\begin{array}{l}\text { Bioenergy Promotion II } \\
\text { (Baltic Sea Region Programme) }\end{array}$ & $80 \%$ & $\begin{array}{l}\text { Fossil fuel based } \\
\text { energy systems }\end{array}$ \\
\hline
\end{tabular}

Sources: Department of Energy and Climate Change [63], Ginter [64], NL Agency [65], Fritsche [66], DONG Energy [48]. 
will be used increasingly for different applications requires clear regulations and minimum standards which apply to all uses of biomass. Without having a consistent and preferably binding biomass sustainability framework at EU level there is a risk of having a patchwork of potentially diverging sustainability regimes and initiatives across Europe causing market intransparency and insecurity for investors.

It can be regarded a promising signal that the European Commission raised its level of ambition regarding the GHG performance of bioenergy pathways compared to the first Biomass Report of 2010. It is likewise positive that energy and resource efficiency gained a more prominent role in recent EU policy documents.

National forest legislation needs to adequately address the specific risks of intensified production and harvesting methods related to forest biomass. The paper revealed that it is at least questionable whether existing governance mechanisms for sustainable forest management in biomass exporting countries are sufficiently robust and effective.

Only few Member States have so far introduced or plan to introduce binding sustainability schemes including lifecycle GHG savings requirements in accordance with the recommendations from the Commission. Most countries rely on overall environmental regulations. However, the paper illustrates that these regulations are not always sufficient due to regulatory gaps and weak enforcement.

The paper also illustrated how problematic policy priorities and policy malfunctioning in two sub-sectors (biogas from energy crops in Germany, biomass co-firing in Poland) led to undesirable environmental and social developments. To mitigate the negative developments associated with biogas production from maize, the German Federal Government gradually amended the Renewable Energy Sources Act, prioritizing the use of residues and wastes over energy crops. However, the recent amendments of 2014 probably fail to effectively unlock the sustainable potential of residues and wastes due to insufficient support rates. In Poland there are some positive signs of a re-orientation of policies towards distributed energy systems and local use of renewable energy sources, although biomass co-firing is still supported, albeit to a lesser extent.

About half of the EU Member States have adopted regulations promoting higher efficiency of bioenergy production (i.e. efficient combined heat and power production). On the other side, biomass co-firing is supported in several EU countries, like UK, Denmark, Belgium, the Netherlands or Poland. The BIOENERGY PROMOTION consortium expressed its concerns regarding biomass co-firing particularly if combined with long distance transports of biomass. Minimum conversion efficiency requirements for fossil and renewable energy plants would safeguard against developing bioenergy options that are efficient in reducing GHG emissions but still inefficient in terms of resource use. Instead, efficient utilization of surplus heat in small to medium scale cogeneration processes can contribute to the decarbonisation of both the heat and electricity sector (see also [9]).

Besides assessing EU and national policy frameworks the paper also examined how industrial stakeholders, particularly energy utilities respond to the growing sustainability concerns associated with biomass. The paper portrayed a number of voluntary biomass sustainability initiatives which recently have been developed on own initiative or as a result of voluntary agreements between national or regional governments and the utilities. There are notable differences in scope, level of ambition, verification procedures and level of independence, as well as chain of custody systems.

The Sustainable Biomass Partnership promises acceptance from energy utilities as it involves some of the biggest market players using biomass in large-scale for power generation which represent 70 per cent of the European wood pellet market. However, a key driver of the initiative is to alleviate global trade of biomass and biomass co-firing in fossil plants or dedicated biomass plants. The scheme might further develop as an authoritative sustainability and certification system for solid biomass, although there exist several other potentially competing certification schemes including the Green Gold Label, another industry-led scheme, the Roundtable on Sustainable Biomaterials, ISCC plus, ENplus, or NTA8080. There are indications of harmonisation between SBP and some of those schemes ${ }^{13}$ [67] [68]. Other schemes like the Roundtable on Sustainable Biomaterials, a multi-stakeholder initiative formerly known as the Roundtable on Sustainable Biofuels, are regarded as more promising approaches from an environmental point of view [69] which might receive broader acceptance among NGOs due to a higher level of ambition and credibility.

\footnotetext{
${ }^{13}$ The participants to Green Gold Label foresee to adopt SBP as the preferred sustainability standard for woody biomass where the use of a certification scheme is applicable [67]. Being a member of the SBP Sounding Board, the European Biomass Association AEBIOM which holds ownership of the ENplus trade mark, is actively collaborating with the SBP. This close collaboration may also lead to the creation of a common sustainability scheme between ENplus and SBP scheme on mid-term [68].
} 


\section{Funding}

Research leading to this paper was conducted in the frame of the projects BIOENERGY PROMOTION and BIOENERGY PROMOTION 2. Both operations received funding from the European Commission under the Baltic Sea Region Programme. Funding was also provided by the German Federal Ministry of Food, Agriculture, and Consumer Protection through its funding programme Renewable Resources.

\section{References}

[1] International Renewable Energy Agency (IRENA) (2013) Statistical Issues: Bioenergy and Distributed Renewable Energy. Working Paper.

http://www.irena.org/DocumentDownloads/Publications/Statistical\%20issues_bioenergy_and_distributed\%20renewabl e\%20_energy.pdf

[2] Council of the European Union (2012) Council Conclusions on Renewable Energy. Transport, Telecommunications and Energy Council Meeting, Brussels, 3 December 2012.

[3] Sikkema, R., et al. (2014) Legal Harvesting, Sustainable Sourcing and Cascaded Use of Wood for Bioenergy: Their Coverage through Existing Certification Frameworks for Sustainable Forest Management. Forests, 5, 2163-2211. http://dx.doi.org/10.3390/f5092163 http://www.mdpi.com/1999-4907/5/9/2163

[4] European Commission (2014) Commission Staff Working Document. State of Play on the Sustainability of Solid and Gaseous Biomass used for Electricity, Heating and Cooling in the EU. SWD (2014) 259 Final, European Commission, Location.

[5] International Institute for Sustainability Analysis and Strategy (IINAS), European Forest Institute (EFI) and Joanneum Research (2014) Forest Biomass for Energy in the EU: Current Trends, Carbon Balance and Sustainable Potential; for BirdLife Europe, EEB and Transport \& Environment. Final Report, Darmstadt, Madrid, Joensuu, Graz. http://www.eeb.org/EEB/?LinkServID=FE1EAF33-5056-B741-DBEF3F46BC26A1E1

[6] Hjulfors, N. and Hjerpe, K. (2010) Sustainable Bioenergy Production-Defining Principles and Criteria. Report Prepared in the Frame of the Bioenergy Promotion Project under the EU Baltic Sea Region Programme. http://www.bioenergypromotion.net/project/publications/task-3.1.-final-report-on-sustainable-production-of-bioenergy

[7] European Commission Joint Research Centre Institute for Energy and Transport (2014) Solid and Gaseous Bioenergy Pathways: Input Values and GHG Emissions. Calculated According to Methodology Set in COM (2010) 11 and SWD (2014) 259. Report EUR 26696 EN. Publications Office of the European Union. Luxembourg.

[8] Bioenergy Promotion 2 (2014) Bioenergy Promotion 2-From Strategies to Activities. Project Results 2014. http://international.fnr.de/fileadmin/fnr-englisch/images/news/BP2 Final Brochure 2014.pdf

[9] European Environment Agency (2013) EU Bioenergy Potential from a Resource-Efficiency Perspective. EEA-Report No. 6/2013. Publications Office of the European Union, Luxembourg.

[10] European Council (2014) European Council (23 and 24 October) Conclusions. European Council, Brussels, EUCO 169/14. CO EUR 13. CONCL 5.

[11] European Commission (2014) Communication from the Commission to the European Parliament, the Council, the European Economic and Social Committee and the Committee of the Regions a Policy Framework for Climate and Energy in the Period from 2020 to 2030. COM (2014) 15 Final, European Commission.

[12] Sachs, I. (2007) The Biofuels Controversy. United Nations Conference on Trade and Development, UNCTAD/DITC/ TED/2007/12. http://unctad.org/en/docs/ditcted200712_en.pdf

[13] Levidow, L. (2013) EU Criteria for Sustainable Biofuel: Accounting for Carbon, Depoliticising Plunder. Geoforum, 44, 211-223. http://dx.doi.org/10.1016/j.geoforum.2012.09.005

[14] Ponte, S. and Daugbjerg, C. (2015) Biofuel Sustainability and the Formation of Transnational Hybrid Governance. Environmental Politics, 24, 96-114. http://dx.doi.org/10.1080/09644016.2014.954776

[15] European Commission (2012) Proposal for a Directive of the European Parliament and of the Council Amending Directive 98/70/EC Relating to the Quality of Petrol and Diesel Fuels and Amending Directive 2009/28/EC on the Promotion of the Use of Energy from Renewable Sources. COM (2012) 595 Final, European Commission.

[16] European Commission (2010) Report on Sustainability Requirements for the Use of Solid and Gaseous Biomass Sources in Electricity, Heating and Cooling. COM (2010) 11 Final, European Commission.

[17] European Commission (2014) Where Next for the European Bioeconomy? The Latest Thinking from the European Bioeconomy Panel and the Standing Committee on Agricultural Research Strategic Working Group (SCAR). Publications Office of the European Union. Luxembourg. 
[18] USDA Foreign Agricultural Service (2015) Dutch Proposal for Biomass Sustainability Criteria. GAIN Report Number: NL5002. http://www.fas.usda.gov/data/netherlands-dutch-proposal-biomass-sustainability-criteria

[19] BirdLife Europe, Greenpeace, European Environmental Bureau, Client Earth and FERN (2012) NGO Briefing: Sustainability Issues for Biomass in Electricity, Heating and Cooling.

http://www.birdlife.org/sites/default/files/attachments/EU-Joint-NGO-briefing-biomass-sustainability-energy-March20 12.pdf

[20] AEBIOM/EBA (2011) AEBIOM and EBA Position Paper-Sustainability Criteria for Solid and Gaseous Biomass. http://www.aebiom.org/blog/aebiom-and-eba-publishes-a-position-paper-on-sustainability-of-solid-and-gaseous-bioma $\underline{\mathrm{SS}}$

[21] AEBIOM/EURELECTRIC (2013) AEBIOM and EURELECTRIC Call for EU Wide Binding Sustainability Criteria for Biomass Now! Press Release.

http://www.aebiom.org/wp-content/uploads/file/Press\%20Releases/AEBIOM\%20Eurelectric\%20press\%20release\%20 FINAL.pdf

[22] European Parliament (2014) European Parliament Resolution of 5 February 2014 on a 2030 Framework for Climate and Energy Policies (2013/2135(INI)). European Parliament.

[23] European Commission (2015) Communication from the Commission to the European Parliament, the Council, the European Economic and Social Committee, the Committee of the Regions and the European Investment Bank: A Framework Strategy for a Resilient Energy Union with a Forward-Looking Climate Change Policy. COM (2015) 80 Final, European Commission.

[24] Eickhout, B. (2012) A Strategy for a Bio-Based Economy. Based on a Study by Jonna Gjaltema and Femke de Jong. Green European Foundation. Green New Deal Series, Vol. 9. http://gef.eu/uploads/media/A_strategy_for_a_bio-based_economy.pdf

[25] Institute for European Environmental Policy (IEEP) (2014) Re-Examining EU Biofuels Policy: A 2030 Perspective. An IEEP Discussion Paper.

http://www.ieep.eu/assets/1359/IEEP_re-examining_EU_biofuels_policy_-_A_2030_perspective.pdf

[26] Biofuelwatch (2013) Coal-to-Biomass Conversions: Supplementing One (Climate) Disaster With Another? Updated Briefing. http://www.biofuelwatch.org.uk/coal-biomass-conversions

[27] Natural Resources Defence Council (NRDC) and Dogwood Alliance (2013) Enviva’s Wood Pellet Mill in Ahoskie, North Carolina Threatens Endangered Ecosystems and Wildlife.

http://www.nrdc.org/energy/forestnotfuel/enviva-wood-pellets.asp

[28] Federal Republic of Germany (2014) Progress Report Pursuant to Article 22 of Directive 2009/28/EC on the Promotion of the Use of Energy from Renewable Sources. Federal Republic of Germany.

[29] Federal Ministry for the Environment, Nature Conservation and Nuclear Safety (2011) The Federal Government’s Energy Concept of 2010 and the Transformation of the Energy System of 2011. http://www.bmu.de/files/english/pdf/application/pdf/energiekonzept_bundesregierung_en.pdf

[30] Fachverband Biogas (2014) Branchenzahlenprognose für die Jahre 2014 und 2015. http://www.biogas.org/edcom/webfvb.nsf/id/DE Branchenzahlen/\$file/14-11-25 Biogas\%20Branchenzahlen Prognos e_2014-2015.pdf

[31] Findeisen, C. (2013) Biogas-Trends in Germany. Biogas as a Key in Future Energy Systems. Biogas Association. Presentation Held on Behalf of BMZ/Federal Ministry for Cooperation and Development. Berlin. http://www.giz.de/fachexpertise/downloads/2013-en-findeisen-biogas-in-germany.pdf

[32] Thrän, D., et al. (2015) IEA Bioenergy Task 40: Country Report Germany 2014. http://www.iinas.org/tl_files/iinas/downloads/bio/IEA_BioT40_2015_Country-Report_Germany_2014.pdf

[33] Johann Heinrich von Thünen-Institut (2009) Grassland Sufficiently Protected? Study of Thünen Institute Provides Insight. http://www.fona.de/en/8669

[34] EurObserv’ER (2014) Biogas Barometer. http://www.energies-renouvelables.org/observ-er/stat_baro/observ/baro224_Biogas_en.pdf

[35] Fachverband Biogas (2013) Branchenzahlenprognose für die Jahre 2013 und 2014. http://www.biogas.org/edcom/webfvb.nsf/id/DE_PM-29-13/\$file/13-11-11_Biogas\%20Branchenzahlen_2013-2014.pd $\underline{f}$

[36] Fachverband Biogas (2014) Fachverband Biogas präsentiert ernüchternde Branchenprognose. http://www.biogas.org/edcom/webfvb.nsf/id/DE_PM-16-14

[37] Scheftelowitz, M., et al. (2014) Entwicklung der Förderung der Stromerzeugung aus Biomasse im Rahmen des EEG. DBFZ Report Nr. 21. Leipzig 2014. https://www.dbfz.de/fileadmin/user_upload/DBFZ_Reports/DBFZ_Report21.pdf 
[38] Polish Ministry of Economy (2010) National Renewable Energy Action Plan. http://ec.europa.eu/energy/sites/ener/files/documents/dir_2009_0028_action_plan_poland.zip

[39] Ministry of Economy (2009) Energy Policy of Poland until 2030. Document Adopted by the Council of Ministers on 10 November 2009. Warsaw, 10 November 2009. Appendix 2. Projection of Demand for Fuels and Energy until 2030. http://www.mg.gov.pl/files/upload/8134/Appendix2.pdf

[40] Ministry of Economy (2015) Energy Policy of Poland until 2050—Draft Ver. 0.2 (In Polish) http://bip.mg.gov.pl/files/PEP2050_v.0.2.pdf

[41] Polska Agencja Prasowa (PAP) (2014) UE uzgodniła Ramy Polityki klimatycznej do $2030 \mathrm{r}$. http://www.pap.pl/palio/html.run?_Instance=cms_www.pap.pl\&_PageID=1\&s=infopakiet\&dz=swiat\&idNewsComp= $181493 \&$ filename $=$ \&idnews $=184804 \&$ data $=$ \&status=biezace \&_CheckSum $=-1698656767$

[42] Polish Parliament (2015) Renewable Energy Act Adopted by the Parliament on 20 February 2015. http://orka.sejm.gov.pl/opinie7.nsf/nazwa/2604_u/\$file/2604_u.pdf

[43] Olszewski, M. (2014) A Polish Appetite for Biomass. http://energytransition.de/2014/ 09/polish-appetite-for-biomass

[44] Kalina, J. (2003) Small-Scale Cogeneration in Poland. OPTI_ENERGY Optimization, Simulation and Environmental Impact of Energy Systems and Processes - Centre of Excellence, Fifth Framework Programme of the European Commission. Institute of Thermal Technology Silesian University of Technology. http://www.itc.polsl.pl/centrum/CHPstudy.pdf

[45] European Commission (2014) Progress towards Achieving the Kyoto and EU 2020 Objective. COM (2014) 689 Final, European Commission.

[46] Eurostat, SHARES (Renewables), SHARES-2013-RESULTS.xlsx. http://ec.europa.eu/eurostat/web/energy/data/shares

[47] Bioenergy Promotion 2 (2013) Report on Assessment of Existing/Emerging Corporate Sustainability Strategies in the Field of Bioenergy.

http://www.bioenergypromotion.net/bsr/publications/report-on-assessment-of-existing-emerging-corporate-sustainabili ty-strategies-in-the-field-of-bioenergy

[48] DONG Energy (2014) DONG Energy Programme for Sustainable Biomass Sourcing (DPSB). Wood Chips and Wood Pellets. Version 1.0.

http://assets.dongenergy.com/DONGEnergyDocuments/com/Responsibility/Documents/2014/DONG Energys Progra mme_for_Sustainable_Biomass_Sourcing_EN.pdf

[49] EurObserv'ER (2015) Solid Biomass Barometer. http://www.energies-renouvelables.org/observ-er/stat baro/observ/baro225 en.pdf

[50] Sustainable Biomass Partnership (2014) Sustainable Biomass Partnership-Key Concepts in the Biomass Assurance Framework.

http://www.sustainablebiomasspartnership.org/docs/draft-consultation/SBP-Key-concepts-in-the-BAF-Consultation-Dr aft-March-2014.pdf

[51] Sustainable Biomass Partnership (2014) Biomass Assurance Framework Standard \#4: Chain of Custody Version 0.0. http://www.sustainablebiomasspartnership.org/docs/Standard04.pdf_Biomass_Sourcing_EN.pdf

[52] Sustainable Biomass Partnership (2014) SBP Stakeholder Consultation on Draft Standards—Consolidated Responses. http://www.sustainablebiomasspartnership.org/docs/SBP-Consolidated-Consultation-Responses.pdf

[53] E.ON AG Department of Corporate Social Responsibility (2009) Biomass Purchasing Amendment to the E.ON Responsible Procurement Policy. Status 31.10.2009.

http://www.eon.com/content/dam/eon-com/de/downloads/e/EON_Biomass_Procurement_Amendment.pdf

[54] Fortum (2011) Sustainability of Bioenergy. Fortums’s Position and Actions. http://www.fortum.com/SiteCollectionDocuments/Sustainability/111221\%20Sustainable-Use-of-Bioenergy_final.pdf

[55] Vattenfall (2015) Our Operations - Biomass. Updated on 21 January 2015. http://corporate.vattenfall.com/about-vattenfall/operations/generation/biomass/

[56] Rácz, K., Wilde-Ramsing, J., van Seters, J. and Scheele, F. (2013) From Whence the Wood? Supply Chain Transparency and the Origin of Solid Biomass for Electricity Generation in the Netherlands. June 2013. SOMO Centre for Research on Multinational Corporations, Amsterdam. http://dx.doi.org/10.2139/ssrn.2297335 http://www.somo.nl/publications-en/Publication_3971

[57] Ernsting, A. (2012) Sustainable Biomass: A Modern Myth. Biofuelwatch. http://globalforestcoalition.org/wp-content/uploads/2012/09/Biofuelwatch-Biomass-Myth.pdf

[58] Fortum (2015) Annual Report 2014. http://apps.fortum.fi/gallery/Fortum_Annual_Report_2014_low.pdf 
[59] Fortum (2014) Sustainability - Annual Report 2013. http://fortum-ar-2013.studio.crasman.fi/pub/web/pdf/Fortum_Sustainability_2013.pdf

[60] Argus Media (2011) Fortum Withdraws from Biomass Buyers Group. Canadian Biomass Magazine. http://www.canadianbiomassmagazine.ca/news/fortum-withdraws-from-biomass-buyers-group-2807\#sthashCZWKq5 $\underline{\text { Xz.dpuf }}$

[61] Land Berlin, Vattenfall Europe AG (2011) Vereinbarung zwischen dem Land Berlin und der Vattenfall Europe AG über Kriterien zur Nachhaltigkeit der Beschaffung von holzartiger Biomasse. http://corporate.vattenfall.de/globalassets/deutschland/geschaeftsfelder/nachhaltigkeitsvereinbarung.pdf

[62] Land Berlin, Vattenfall (2013) Nachhaltigkeitsbericht für die Jahre 2011 und 2012 über die Beschaffung holzartiger Biomasse durch Vattenfall. http://corporate.vattenfall.de/globalassets/deutschland/geschaeftsfelder/nachhaltigkeitsbericht_2013.pdf

[63] Department of Energy \& Climate Change (2013) New Biomass Sustainability Criteria to Provide Certainty for Investors to 2027. https://www.gov.uk/government/news/new-biomass-sustainability-criteria-to-provide-certainty-for-investors-to-2027

[64] Ginter, S. (2013) UK Sustainability Criteria Provide Policy Certainty. Biomass Magazine. http://biomassmagazine.com/articles/9454/uk-sustainability-criteria-provide-policy-certainty

[65] NL Agency (2013) Sustainable Biomass NPSB Information Bulletin Nr. http://english.rvo.nl/sites/default/files/2013/12/NPSB\%20Information\%20Bulletin\%201_2013_def.pdf

[66] Fritsche, U.R. (2012) Sustainable Bioenergy. Key Criteria and Indicators. Final D4.1 Delivery of the Biomass Futures Project Funded by Intelligent Energy Europe. Darmstadt March 2012. http://www.biomassfutures.eu/public docs/final deliverables/WP4/D4.1\%20Sustainable\%20Bioenergy\%20-\%20criter ia\%20and\%20indicators.pdf

[67] Green Gold Label (2015) Welcome to the Green Gold Label. http://www.greengoldcertified.org/site/pagina.php

[68] Gauthier, G. (2014) D4.6. Sustainability Scheme. AEBIOM. Report Prepared under the PellCert Project. http://www.enplus-pellets.eu/wp-content/uploads/2014/07/D-4.6-sustainability-scheme.pdf

[69] Fritsche, U.R., Iriarte, L., Fitzgerald, J. and Bird, N. (2014) Sustainability Assurance for Energy from Forestry. Final Report Prepared for WWF International. http://www.iinas.org/Biomasse-Projekte.html 